\title{
El arte de acomodarse a dos mundos: la vida de don Pedro de Moctezuma Tlacahuepantli según los documentos del Archivo General de la Nación (México D.F.) y el Archivo General de Indias (Sevilla, España)
}

\author{
Anastasia V. KalyutA \\ Museo Ruso de Etnografía \\ anastasiakalyuta@rambler.ru
}

Recibido: 18 de enero de 2011

Aceptado: 14 de febrero de 2011

\section{RESUMEN}

El presente artículo se centra en el análisis de la documentación de archivo sobre la vida de don Pedro de Moctezuma Tlacahuepantli, el hijo menor del huey tlahtoani mexica Motecuhzoma Xocoyotzin y de la «princesa» de Tollan Xicocotitlan Miahuaxochtzin. En su biografía se enlazan varios aspectos del drama social que sufrió la nobleza indígena después de la llegada de Hernando Cortés, y al mismo tiempo se reflejan las estrategias principales de adaptación que los descendientes de los gobernantes prehispánicos del Altiplano tuvieron que aprender para acomodarse a las nuevas realidades. El artículo tiene como objetivos presentar una nueva versión de la biografía de don Pedro de Moctezuma, basándose en la síntesis de los documentos del Archivo General de la Nación y del Archivo General de Indias, y estudiar, a través de esas evidencias documentales, la relación entre las concepciones nahuas y castellanas sobre la herencia y la transmisión del rango social y los derechos a ciertas propiedades por lazos de sangre.

Palabras clave: Nobleza nahua, Conquista, complejidad cultural, adaptación.

\section{The Art of Accommodation to Two Worlds: The Life of don Pedro de Moctezuma} Tlacahuepantli According to the Documentation of the General Archive of Nation (Mexico City, Mexico) and the General Archive of Indies (Seville, Spain)

\section{ABSTRACT}

This paper analyses archival documentation about the life of don Pedro de Moctezuma Tlacahuepantli, the youngest son of the Mexica huey tlahtoani Motecuhzoma Xocoyotzin and the Tollan Xicocotitlan «princess» Miahuaxochitl. His biography embraces various aspects of the social drama that the indigenous nobility suffered after the arrival of Hernando Cortes, and at the same time reflects the main adaptive strategies which the descendants of the Prehispanic rulers had to learn to accommodate themselves to the new reality. The article pursues two objectives: 1) to present a new version of don Pedro de Moctezuma's biography, based on the synthesis of the documentation from the Archivo General de la Nación and the Archivo General de Indias; 2) to examine in the light of this evidence the relationship between Nahua and Castilian concepts of inheritance and transmission of social rank and rights to certain properties by the ties of blood.

Key words: Nahua nobility, the Spanish Conquest, cultural complexity, adaptation.

Sumario: 1.Introducción.2.Antecedentes:elaltepetldeTollanXicocotitlanylospríncipesmexica-tenochcas en los siglos XIV-XVI. 3. Los primeros años de don Pedro, 1512-1523. 4. Entre los nahuas y los españoles, 1523-1540.5. La lucha por las tierras de Tollan Xicocotitlan, 1541-1557. 6. ¿Victorias pírricas? 1557-1570.

7. Referencias documentales. 8. Referencias bibliográficas. 


\section{Introducción}

Quedaron muchos hijos deste Moteczuma á lo que dicen algunos. Cortés dice que dejó tres hijos varones con muchas hijas. El mayor de ellos murió entre muchos españoles al huir de Mejico...Don Pedro Moteczuma, que aun vive, es su hijo, y señor de un barrio de Mejico, el cual, porque se da mucho por vino, no le han hecho mayor señor.

Francisco López de Gómara, Hispania Victrix.

Así, con evidente desprecio, describe el primer biógrafo y secretario privado de Hernando Cortés, a don Pedro de Moctezuma Tlacahuepantli, uno de los hijos menores del huey tlahtoani (gobernante supremo) mexica-tenochca Motecuhzoma Xocoyotzin, más conocido en el mundo europeo como Moctezuma II, habido en Miahuaxochitl con la hija de su medio hermano Ixtlilcuechahuacatl, el tlahtoani de la antigua ciudad de Tollan Xicocotitlan en el actual estado de Hidalgo (Alvarado Tezozomoc 1975: 134, 138,150-152; AGN, Vínculos y mayorazgos 256, cuad. 12, exp. 1, f. 18r). Sin embargo, hay otros testimonios que nos proporcionan pistas sobre la personalidad de este príncipe tenochca. Por ejemplo, el cronista indígena Hernando Alvarado Tezozomoc, sobrino de don Pedro, nos informa en el discurso que abre la Crónica Mexicayotl, que su tío fue uno de los que le enseñó «la antigua palabra» huehuetlatolli - las narraciones orales, que comprendían la tradición mítica e histórica de los mexicas (Alvarado Tezozomoc 1975: 9). También sabemos que él viajó dos veces a España, en torno a 1528 y 1540, (Ramírez Calva 2005: 156; Jiménez Abollado 2008: 52; AGN, Vínculos y mayorazgos 256, cuad. 12, exp. 1, f. $78 \mathrm{r})$. En aquel tiempo de transportes inseguros y de corsarios franceses, ingleses y argelinos que perseguían a los navíos españoles, el viaje era una empresa costosa, arriesgada, y además no siempre permitida a la nobleza indígena. Basta decir que, por ejemplo, don Hernando Pimentel, el nieto del tlahtoani tetzcocano Nezahualcoyotl y gobernador colonial de Tetzcoco, solicitaba en vano permiso para ir a España (Pimentel 2000: 257). Hay otro detalle de mucho interés; en su última carta al rey Felipe II, de 31 de marzo de 1569, don Pedro, entre otras cosas, respalda al licenciado Alonso Muñoz, juez pesquisidor del Real Consejo de Indias, que vino a investigar la conspiración de Martín Cortés, el hijo mayor del conquistador y de Alonso Davila y trató de protegerle contra los cargos levantados por sus enemigos en la Audiencia Real de México, una situación que poco se corresponde con la visión tradicional de la nobleza indígena humillada y privada de influencia en la vida política de la Nueva España ${ }^{1}$.

1 «El licenciado Alonso Muñoz del Real Consejo sirvió mucho a Vuestra Magestad y tuvo esta tierra en toda paz e justicia y sosiego el tiempo que estuvo en ella y la governó y me favoreció y ayudó a mi y a mis deudos y limpió estos reynos de malas gentes, por lo cual quedó mal visto de los justiçiados e de letrados e de sus de sus deudos que son muchos e por momentos le levantaron mil testimonios y maldades, cosa usada en las Indias contra los que tratan el servicio de Vuestra Magestad y bien de los indios y su doctrina, como el dicho licenciado lo hizo. Mande Vuestra Magestad honrralle y estimalle ... y no se ha de dar credito a lo que malas gentes le levantasen e dijesen» (AGI, Patronato Real 245, R. 4, exp. 1, f. 5v). 
Algunos datos sobre las actividades y la posición de don Pedro de Moctezuma en la sociedad novohispana, desmienten también la imagen despectiva de López de Gomara. El hijo del último huey tlahtoani mexica aparece como una figura de importancia tanto en el mundo indígena, como en el ambiente español, como un hombre enérgico y capaz de adaptarse a nuevas realidades complejas sin perder totalmente su legado ancestral. Durante casi toda su vida don Pedro tuvo que luchar para ser reconocido como heredero legítimo de su padre y continuar el linaje de los señores mexica-tenochcas. Gran parte de los conflictos que afectaron a su vida, tuvieron sus orígenes en acontecimientos sucedidos mucho antes de su nacimiento, en los siglos XIV-XV. Así, para comprender las motivaciones de don Pedro y sus oponentes, es indispensable repasar brevemente las relaciones entre dos altepetl del Altiplano Central del Postclásico Tardío, de donde procedían los ancestros de nuestro personaje, México Tenochtitlan y Tollan Xicocotitlan.

\section{Antecedentes: el altepetl de Tollan Xicocotitlan y los príncipes mexica- tenochcas en los siglos XIV-XVI}

Uno de los eventos que determinó el curso de la vida de don Pedro, fue la alianza política entre Tenochtitlan y Tollan Xicocotitlan en torno a 1369. Las fuentes del periodo colonial temprano presentan diferentes versiones de este evento, que obviamente reflejan las distintas visiones de sus creadores. Según un documento inédito del AGN, que se titula la Relación de la claridad y demanda de don Pedro y su madre, fue el tlahtoani de Tollan Xicocotitlan Zozomatecuhtli quien mandó al primer tlahtoani tenochca, Acamapichtli, una embajada con la propuesta de «tomar amistad y parentesco con él en que le diese un hijo [a] casar con una hija de dicho Susumatecle» (AGN, Vínculos y mayorazgos 256, cuad. 1, exp. 1, f. 18r). En este documento se afirma que Acamapichtli aceptó la propuesta de buena gana y envió a Tollan Xicocotitlan a su hijo Cuitlachtli que se casó con la hija de Zozomatecuhtli Xiloxochtzin, tuvo cinco hijos con ella, y con el tiempo sucedió a Zozomatecuhtli como tlahtoani de Tollan Xicocotitlan (AGN, Vínculos y mayorazgos 256, cuad. 12, exp. 1, f. 18r). La Relación añade que Acamapichtli ordenó dar a los recién casados las tierras de 10 estancias (es decir pueblos sujetos al altepetl principal) alrededor de Tollan Xicocotitlan: Acocolco, Teçontepetonco, Yztactzaquala, Tlaquixtiloyan, Toltenco, Techichilco, Teapan, Huapalcalco, Ahuehuepan, Ylocan, que posteriormente se repartieron entre todos los vástagos de la pareja, incluso su hija Azcaxochitl, la tatarabuela de don Pedro (véase Figura 1). Es importante decir que, tras la Conquista, justamente esas tierras junto con otras 11 estancias, se convertieron en manzana de discordia entre don Pedro y el cabildo de Tollan Xicocotitlan. Esta versión se confirma parcialmente en la Crónica Mexicayotl de Hernando Alvarado Tezozomoc, en la Tercera y la Séptima Relaciones de Domingo Francisco Chimalpahin (Alvarado Tezozomoc 1975: 138; Chimalpahin 2003-1: 272; 2: 113-114). Ambos autores mencionan la entronización de Cuitlachtli en Tollan Xicocotitlan, y Chimalpahin dice que este evento tuvo lugar de acuerdo con la petición de los pipiltin (nobles) de Tula 


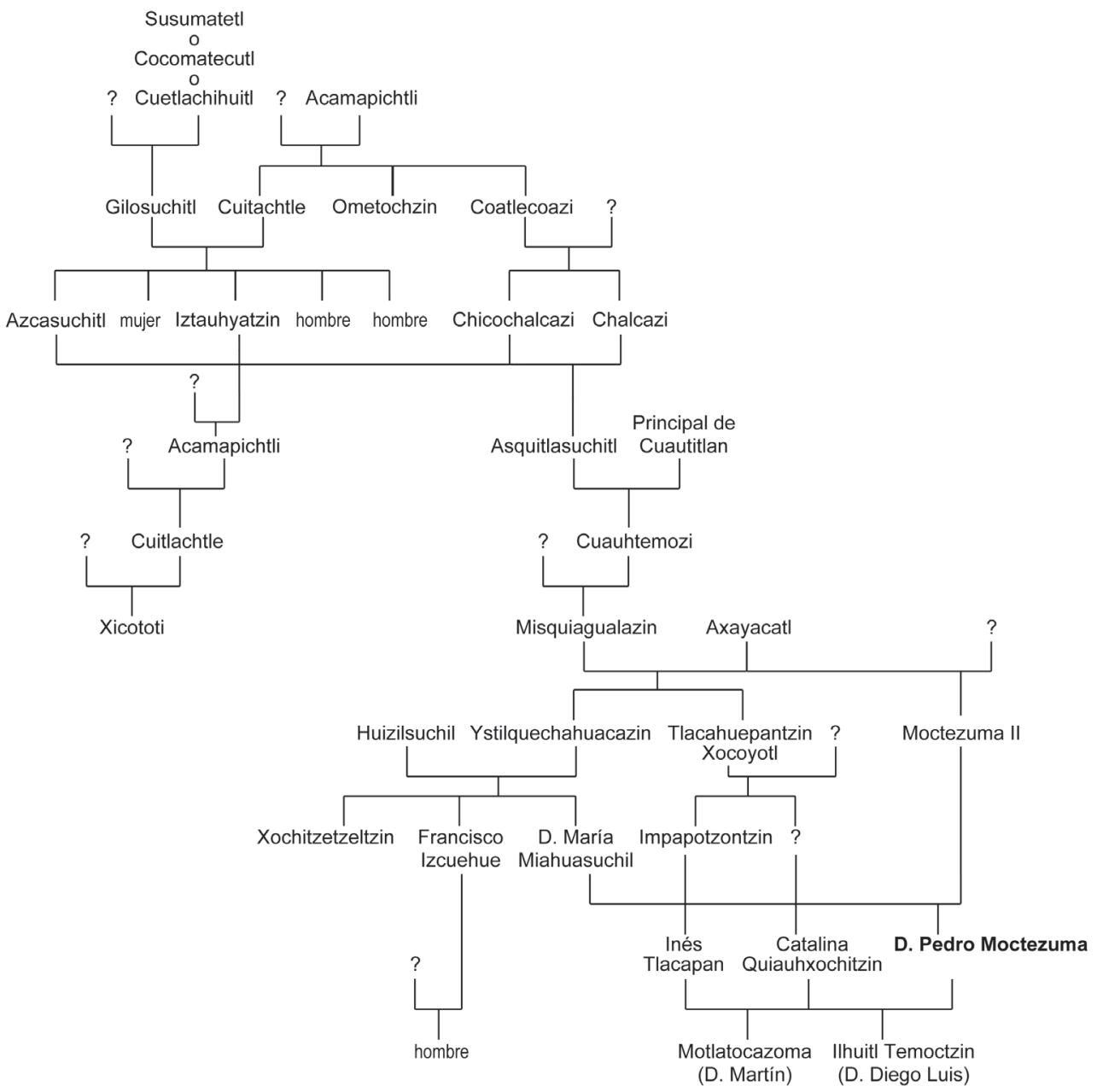

Figura 1: Genealogía de don Pedro de Moctezuma Tlacahuepantli (según Ramírez Calva 2005: 85).

en 1366 (Chimalpahin 2003-2: 114-115). Sin embargo, este último autor afirma que, al principio, Acamapichtli envió a Tollan Xicocotitlan a su otro hijo, Ometochtli, no para casarse sino para gobernar allá, pero Ometochtli murió en cuanto llegó a Tollan Xicocotitlan y entoncés Cuitlachtli le sucedió ese mismo año (Chimalpahin 20032: 114). Esta variante coincide con la versión de los Anales de Tula, salvo en que en esta última fuente el segundo hijo de Acamapichtli no se llama Cuitlachtli sino Coxcox (Anales de Tula 1979: 33). En la Tercera Relación, Chimalpahin también menciona el casamiento de Cuitlachtli con Xiloxochtzin, pero dice que su padre se llamaba Cuetlachihuitl (Chimalpahin 2003 vol. 1: 227). Cabe notar que para ambos 
cronistas Cuitlachtli fue el primer tlahtoani de Tollan Xicocotitlan y fundador de su tlahtocayotl, es decir, del gobierno de un tlahtoani y de su linaje gubernamental. De hecho, los descendientes de Cuitlachtli, incluso don Pedro, gobernaron en Tollan Xicocotitlan hasta la década de 1530. Finalmente, Juan Damian, el procurador indígena del cabildo de Tollan Xicocotitlan durante el litigio con don Pedro en 15411557, en una carta de apelación fechada el 27 de diciembre de 1557, dice que el primer tlahtoani de Tollan Xicocotitlan fue Zozomatecuhtli y que su yerno Cuitlachtli vino a sucederle, fundando la nueva dinastía de los tlahtoque (AGN, Vínculos y mayorazgos 256, cuad. 12, exp. 1, f. 319v). Sin embargo, Juan Damian no menciona ninguna embajada de Zozomatecuhtli a Tenochtitlan.

Lamentablemente sabemos poco de las fuentes procedentes del actual estado de Hidalgo. Se puede suponer sobre la base de la semejanza de testimonios, que todas las versiones más arriba examinadas proceden de una tradición prehispánica común. Por ejemplo, se puede notar que Chimalpahin copió la Crónica Mexicayotl para sus propios escritos y, como hemos dicho, uno de los informantes principales de Hernando Alvarado Tezozomoc fue su tío don Pedro de Moctezuma Tlacahuepantli. Se menciona varias veces también que don Pedro tenía a su dispocisión unas «pynturas», es decir, los códices «pictóricos» que usaba para hacer sus probanzas y lo mismo hacían sus oponentes del cabildo de Tollan Xicocotitlan (AGN, Vínculos y mayorazgos 256, cuad. 12, exp. 1, ff. 3, 6r, 283v, 319v). Dado el contenido similar de las fuentes escritas y basándose en estas «pynturas» perdidas, se puede deducir que estos documentos compuestos según el patrón prehispánico, eran de carácter muy semejante a los Anales de Tula, hoy la única fuente «pictórica» procedente de Tollan Xicocotitlan, y contenían información sobre la transmisión del poder y la genealogía de los gobernantes prehispánicos del altepetl, aunque ahora no es posible saber si los Anales de Tula fue una de las «pynturas» que usaron don Pedro o sus oponentes durante el litigio de 1541-1557. No podemos excluir que los Anales de Tula sea una copia tardía de los códices prehispánicos que estaban a disposición de los pipiltin de Tollan Xicocotitlan. Hay que señalar que en todas las versiones examinadas, salvo la de Juan Damian, el primer tlahtoani tenochca ya se representa como gobernante que tiene poder evidente sobre el altepetl de Tollan Xicocotitlan. Acamapichtli reparte las tierras del altepetl e impone sus hijos como gobernantes de Tollan Xicocotitlan, uno tras otro, actitud que en la Mesoamérica Prehispánica se asociaba con una posición dominante sobre la unidad política en cuestión (AGN, Vínculos y mayorazgos 256, cuad. 12, exp. 1, f. 18r; Chimalpahin 2003 vol. 2: 114). Para completar el cuadro, es necesario añadir que en la última de las tres cartas de don Pablo Nazareo, un noble indígena de Xaltocan emparentado con la dinastía de los tlahtoque mexica-tenochcas, fechada el 17 de marzo de 1566, Tollan Xicocotitlan se menciona entre las conquistas del segundo tlahtoani tenochca Huitzilhuitl (Nazareo 2000: 348). Se puede deducir que los relatos de don Pedro, de su sobrino Tezozomoc y de Chimalpahin, reflejan la versión mexica de los eventos, en la que Tenochtitlan se presentaba como el mayor de dos altepetl que ejercía control político sobre Tollan Xicocotitlan ya desde la segunda mitad del siglo XIV. 
La situación real habría sido muy diferente, ya que en los años sesenta de 1300 , tanto Tollan Xicocotitlan como Tenochtitlan eran igualmente centros pequeños y débiles bajo el dominio de Azcapotzalco, la poderosa urbe tepaneca situada al noroeste de la Cuenca de México, que por entonces era el poder principal en buena parte del Altiplano Central. Curiosamente lo confiesan el mismo don Pedro y su madre diciendo en la Relación que «al tiempo el dicho casamiento hobo efecto el dicho pueblo de Tula era muy poca cosa y otomíes pobres y lo mismo a la dicha sazón lo era esta dicha ciudad de México» (AGN, Vínculos y mayorazgos 256, cuad. 12, exp. 1, f. 18r). Además, Chimalpahin en su Tercera Relación, fecha la entronización de Acamapichtli en Tenochtitlan hacia el año 7 Casa o sea 1369 (Chimalpahin 2003 vol. 1: 222-223). Obviamente, en el momento de establecer la alianza dinástica, ambos altepetl ocupaban casi la misma escala en la jerarquía política de los estados del Altiplano Central, y posiblemente Tenochtitlan, siendo una población recién fundada, estaba más interesada en la alianza con Tollan Xicocotitlan que esta última. Los mexica compartían con otros grupos del Postclásico Tardío la noción sobre Tollan Xicocotitlan como el centro más sagrado de poder, la sede de Topiltzin Quetzalcoatl, dios-creador de la humanidad y de la civilización, de donde surgió la misma institución del tlahtocayotl (López Lujan y López Austin 2009: 384). Además, para los mexicas Tollan Xicocotitlan era una parada en su camino mítico a la Cuenca de México, donde ellos dejaron gente de «su descendencia y generación» (Alvarado Tezozomoc 2001: 55). De hecho, los hallazgos arquelógicos de mediados del siglo XX confirman la presencia mexica tanto en el valle del río Tula, como en el mismo sitio arquelógico de Tula Grande en el siglo XIV. Según J. Acosta, en Tula Grande la cerámica del tipo azteca III asociada con los mexicas se encuentra a veces mezclada con el complejo cerámico tolteca (Acosta 1940: 187, 188; Acosta 1956: 57, 75). Así, se puede suponer que los gobernantes del nuevo altepetl de Tenochtitlan, cuya posición al principio fue más bien precaria, buscaban vías no sólo para reunirse con los mexicas de Tollan Xicocotitlan, sino también para fortalecer sus pretensiones al legado tolteca.

Entre 1426-1431, durante el reinado del nieto de Cuitlachtli, Acamapichtli, el altepetl de Tollan Xicocotitlan, sufrió una crisis interna muy dura, posiblemente causada por las contradicciones internas entre diferentes comunidades que formaban esta entidad polítíca (Anales de Tula 1979: 35). Una fuente la describe como «guerra entre nosotros» (Pérez Rocha y Tena 2000: 144-145). El cuarto tlahtoani mexica-tenochca Itzcoatl, él mismo hijo de Acamapichtli de Tenochtitlan, no tardó en aprovecharse de este conflicto para mandar a Tollan Xicocotitlan sus guerreros y apoderarse no sólo de las diez estancias concedidas a Cuitlachtli y su esposa, sino de otras cinco: Yztla, Milpan, Tlaltzonco, Tepeitec, Huapalcalco, que posiblemente formaban parte de las tlahtocamilli, o sea de las tierras, vínculadas con el cargo de tlahtoani de Tollan Xicocotitlan (Pérez Rocha y Tena 2000: 145). Obviamente, las 15 estancias pasaron a la categoría de pillalli, es decir, las tierras heredetarias de los miembros de la dinastia mexica-tenochca, sobre todo de los nietos del mismo Itzcoatl, habidos en alianza matrimonial entre Tezozomoctli, el hijo de Itzcoatl y Atotoztli, la hija del quinto huey tlahtoani tenochca Motecuhzoma Ilhuicamina (Alvarado Tezozomoc 1975: 143). Según los testimonios procedentes de enemigos furibundos de don Pedro, los pipiltin 
del cabildo de Tollan Xicocotitlan, sus abuelos nunca reconocieron esta nueva «repartición», pero tuvieron que aceptarla a regañadientes (Pérez Rocha y Tena 2000: 145). Por entonces Tenochtitlan ya había vencido a sus antiguos señores, los tepanecas de Azcapotzalco, y estaba convirtiéndose poco a poco en el altepetl más poderoso de todo el Altiplano Central. Su nueva posición le permitía realizar una política expansionista y entrometerse en asuntos internos de sus vecinos, y tomar y repartir las tierras en el territorio de los altepetl vencidos o sometidos bajo su control. No en vano la tradición de la Crónica $\mathrm{X}$ relaciona el reinado de Itzcoatl con la distribución de las tierras en la Cuenca de México entre los pipiltin mexica-tenochcas, sobre todo entre los miembros del linaje de los tlahtoque de Tenochtitlan y con la formación de grandes «heredades» de los príncipes tenochcas (Alvarado Tezozomoc 2001: 99,102$103,105,113,132-133)$.

Durante los últimos 90 años antes de la Conquista, el control tenochca sobre Tollan Xicocotitlan siguió creciendo de pleno acuerdo con la expansión general de Tenochtitlan. Según la carta-apelación de Juan Damian, a partir de la muerte del tlahtoani Xicohtlohtli, el bisnieto de Cuitlachtli hacia 1480, los nobles del altepetl tenían que ir cada vez a Tenochtitlan para pedir allí un nuevo gobernante, siempre de la dinastía tenochca (AGN, Vínculos y mayorazgos 256, cuad. 12, exp. 1, f. 319v). El nieto de Itzcoatl, el tlahtoani Axayacatl, contrajo matrimonio con la bisnieta de Cuitlachtli, la «princesa» Mizquixahualtzin. De ella Axayacatl tuvo dos hijos: Tlacahuepantli el Viejo, que gobernó en Tenayucan, e Ixtlilcuechahuacatl, el último tlahtoani prehispánico de Tollan Xicocotitlan y abuelo materno de don Pedro de Moctezuma (véase Figura 1). Axayacatl no solo heredó las quince estancias de su abuelo, sino que compró tres más: Tlatilco, Huapantla y Tulpan (este último fue el sitio del mercado del altepetl de Tollan Xicocotitlan) «por cuarenta camisas, sesenta mantas coloradas muy ricas y veynte cargas de algodon y cien cargas de mayz». (AGN, Vínculos y mayorazgos 256, cuad. 12, exp. 1, f. 18v). Dejando aparte la cuestión muy debatida de si en la sociedad prehispánica la tierra era considerada como una mercancía, puesto que este problema requiere un estudio separado, nos limitaremos sólo a decir que ciertas menciones de compra y venta de las tierras aparecen de vez en cuando en la documentación de archivo. Sin embargo, su número es extremadamente escaso y siempre se trata de transacciones entre la nobleza indígena. Es cierto que en todos estos casos como «moneda» se usaban mantas de algodon, varios artículos de ropa y productos agrícolas. Las estancias tolanenses de Tepetitlan, Atiltalaquian e Yztla llegaron a formar las pillalli o «tierras patrimoniales», en terminología castellana, de otro nieto de Itzcoatl, el tlahtoani Ahuitzotl, que a su vez logró transmitirlas a su hija Tecalco, la esposa principal de Motecuhzoma Xocoyotzin (Pérez Rocha 1998: 27, 133, 155). Según la Información de doña Isabel de Moctezuma, al casarse con Tecalco, Motecuhzoma obtuvo poder sobre todas las tierras dotales de su esposa incluso las de Tollan Xicocotitlan (Pérez Rocha 1998: 133). Como ya hemos dicho, Motecuhzoma también siguió la politica matrimonial de su padre, contrayendo nupcias con otra «princesa tolteca», su propia sobrina Miahuaxochitl (véase Figura 1). «La princesa» se fue a vivir a Tenochtitlan con su esposo y en consecuencia los tributos de sus tierras también llegaban a los almacenes del tecpan de Motecuhzoma Xocoyotzin (AGN, Vínculos y 
mayorazgos 256, cuad. 12, exp. 1, f. 80r). Gracias a la política de intervención de sus ancestros y a sus propias alianzas matrimoniales, Motecuhzoma logró concentrar en sus manos la mayor parte de las tierras de Tollan Xicocotitlan, convirtiéndolas en sus pillalli, manteniendo así un dominio indiscutible sobre este altepetl. Es importante señalar que ni Tollan Xicocotitlan, ni sus pueblos sujetos aparecen en el Códice Mendocino como tributarios del estado mexica. Así se puede deducir que, en vísperas de la Conquista, gran parte de las tierras de Tollan Xicocotitlan estaba en poder de los miembros del linaje mexica-tenochca, tanto de la rama que gobernaba este altepetl, como de sus primos en Mexico-Tenochtitlan.

La muerte prematura de Ixtlilcuechahuacatl, quien murió en combate con atlixcas y huexotzincas hacia 1507, y los cuatro años posteriores de interregnum en Tollan Xicocotitlan, debieron aumentar aún más el poder personal de Motecuhzoma Xocoyotzin en el lugar. Luego, en torno a 1511, Motecuhzoma impuso en Tollan Xicocotitlan a su sobrino Xochitzetzeltzin, uno de los hijos del difunto Ixtlilcuechahuacatl (AGN, Vínculos y mayorazgos 256, cuad. 12, exp. 1, f. 319v; Anales de Tula 1979: 39). Obviamente esta situación no podía complacer a gran parte de los pipiltin de Tollan Xicocotitlan, especialmente a los de origen étnico distinto: otomi o tepaneca. Parece que ellos nunca reconocieron a los príncipes mexica-tenochcas como a sus gobernantes legítimos y los veían como unos intrusos indeseables. Sus descendientes heredaron esa fuerte antipatía hacia el mismo don Pedro, aumentada como consecuencia de un prolongado litigio. Por ejemplo, hacia 1561-1562, los pipiltin de Tollan Xicocotitlan solían «saludar» a don Pedro con las siguientes palabras: "Anda, vete a México, que es tu tierra y deja a Tula [es decir Tollan Xicocotitlan], que no tienes nada en ella» (AGN, Vínculos y mayorazgos 255, cuad. 8, exp. 1, f. 71).

En suma, el ambiente, en que nació el pequeño príncipe tenochca era competitivo y lleno de tensiones internas. La llegada de los españoles aumentó esas tensiones hasta convertirlas en conflictos abiertos, aunque desde entonces la lucha se desarolló en el corregimiento de Tollan Xicocotitlan, la Real Audiencia de México e incluso en la corte imperial.

\section{Los primeros años de don Pedro, 1512-1523}

Se desconoce la fecha exacta del nacimiento de don Pedro. En su libro Los hijos de Moctezuma: La realeza azteca bajo el dominio español (2005), el autor norteamericano Donald Chipman supone que Tlacahuepantli habría nacido hacía 1503, poco después de la entronización de su padre (Chipman 2005: 82). Lamentablemente, como en otros casos, Chipman no cita ninguna fuente para confirmar su suposición y nos parece que su afirmación carece de valor sin referencias probadas. Se conoce otro testimonio documental que permite fechar el nacimiento de don Pedro en torno a 1512. Es la Probanza de don Martín de Moctezuma Motlatocazoma, que era el hijo mayor y principal heredero de don Pedro, fechada en 1572. En este documento, uno de los testigos, Marcos Montejo, esclavo del conquistador Francisco de Montejo, afirma que estaba en Tenochtitlan en junio de 1520, donde conoció a Motecuhzoma 
Xocoyotzin, Miahuaxochitl y su hijo Tlacahuepantli, quien por entonces tendría entre 7 y 8 años (AGN, Tierras, vol. 2627, exp. 1, f. 917v). Esta declaración en cierto modo coincide con otro testimonio del mismo documento. Otro testigo de la Probanza de don Martín de Moctezuma Motlatocazoma, llamado Pedro García, indígena, natural del barrio de San Hipólito de la ciudad de México, de la avanzada edad de 102 años ( isic!), declara que en 1520 don Pedro todavía era muchacho, aunque no indica su edad exacta (AGN, Tierras, vol. 2627, exp. 1, f. 933r). A pesar de que no resulta del todo claro porqué Marcos Montejo no se fue con su dueño a España en 1519, cuando Cortés le mandó con los presentes de Motecuhzoma Xocoyotzin a Carlos V, se puede aceptar este testimonio y el de Pedro García como provisionales. Además, hay unas pruebas indirectas a favor de su veracidad. En la Cronica Mexicayotl de Hernando Alvarado Tezozomoc, don Pedro ocupa el noveno y último puesto, tras todos los demás hijos varones en el listado de los 19 hijos de Motecuhzoma (Alvarado Tezozomoc 1975: 151). Aunque la Crónica Mexicana del mismo autor menciona sólo 7 hijos varones del huey tlahtoani, en este segundo listado don Pedro también se encuentra en el último lugar (Alvarado Tezozomoc 2001: 481). Tomando en cuenta la importancia del orden de nacimiento en la sociedad nahuatl prehispánica, reflejada en la misma terminología de parentesco, se puede suponer que don Pedro era realmente el menor de los hijos varones de Motecuhzoma Xocoyotzin y desde luego podría haber nacido hacia 1512.

En su última carta, de 31 de marzo de 1569, don Pedro menciona a sus hermanas, que por entonces vivían con él (AGI, Patronato Real 245, R.4, exp. 1, f. 4v). Obviamente no se trata ni de doña Isabel de Moctezuma, que murio en 1550, ni de doña Leonor de Moctezuma y Valderama que también falleció mucho antes de 1569 (López de Meneses 1949: 495; Pérez Rocha, Tena 2000: 259). No obstante, ninguna otra fuente dice que Motecuhzoma y Miahuaxochitl tuvieran otros hijos salvo Tlacahuepantli. Tal vez don Pedro podía hablar de sus otras hermanastras, ya que se sabe que Motecuhzoma tuvo 10 hijas (Alvarado Tezozomoc 1975: 153).

El nombre nahuatl de don Pedro, Tlacahuepantli, puede traducirse como el «hombre de madera» o más probablemente como derivación de dos palabras, tlacahue «poseedor de cortaduras» y epatl, mofeta, uno de los nahuales de Tezcatlipoca ${ }^{2}$. De hecho Tlacahuepantli Cuezcotzin es una de las deidades que pertenecen al complejo Huitzilopochtli-Tezcatlipoca (Sahagún 1979: vol. 1, lib. 2, f. 118r). Como tal, se representa, ora como hermano menor y compañero de Huitzilopochtli, ora como uno de los numerosos avatares de Tezcatlipoca, especialmente en la lucha de este dios con Quetzalcoatl Topiltzin y los toltecas. Su posición, inferior a la de Huitzilopochtli, se refleja también en su otro nombre, Teicauhtzin, «el hermanito menor» (Sahagún 1979: vol. 1, lib. 2, f. 91r). En la fiesta de Panquetzaliztli se hacían las figuras de ambas deidades con bledos que luego se subían a lo alto del Templo Mayor (Sahagún

\footnotetext{
${ }^{2}$ Chimalpahin en su Septima relación menciona el segundo nombre nahua de don Pedro Yohualicahuacatzin («el venerable poseedor de noche» o «el que se detiene en la noche») posiblemente otra referencia a Tezcatlipoca. Este nombra también provoca asociaciones con uno de los epitetos constantes de Xipe Totec Yohuallahuan, «el que se embriaga por la noche». Cabe señalar que Xipe frecuentamente se asocia con Tezcatlipoca como «el Tezcatlipoca rojo».
} 
1979, vol. 1, lib. 2, f. 109r). Así, Tlacahuepantli era el gemelo menor de Huitzilopochtli, como Quetzalcoatl lo era de Xolotl. Pero no se pueden perder de vista tampoco sus fuertes vínculos con Tollan Xicocotitlan, donde este personaje generalmente figura como uno de los avatares malignos de Tezcatlipoca. Tlacahuepantli aparece como un gigante espantoso, cuya muerte y descomposición había acarreado una peste que destruyó Tollan (Sahagún 1979: vol. 1, lib 3, f. 17). En otro mito, también incluido en la Historia General de las Cosas de la Nueva España, Tlacahuepantli es uno de tres «nigrománticos», junto con Huitzilopochtli y Tezcatlipoca que hechizaron a los toltecas (Sahagún 1979: vol. 1, lib. 2, f. 37).

Tomando en cuenta la creencia de los nahuas en el poder de la palabra, se puede suponer que el niño fue considerado desde su nacimiento como tlahtoani potencial de Tollan Xicocotitlan y su nombre nahuatl, asociado al mismo tiempo con el «hermano menor» y gemelo de Huitzilopochtli y el avatar de Tezcatlipoca que conquistó Tollan con sus artes mágicas, habría sido escogido con intención de hacer realidad su futuro papel en las relaciones entre los dos altepetl. En la Relación de 1543 se afirma que ya por entonces Motecuhzoma donó a su hijo menor las 10 estancias arriba mencionadas (AGN, Vínculos y mayorazgos 256, cuad. 12, exp. 1, f. 18v).

Nada se sabe de los primeros años de la vida de Tlacahuepantli. Ni siquiera se conoce dónde y cómo pudo recibir la educación indicada para un hijo del huey tlahtoani y aprender tan perfectamente el «antiguo precioso legado». Fray Bernardino de Sahagún nos informa que «los señores, o principales o viejos ancianos ofrecían sus hijos a la casa que se llamava calmecac», donde «les enseñavan todos los versos de canto para cantar: los quales estavan escritos en sus libros por caracteres. Y mas les enseñavan la astrologia yndiana y las interpetaciones de los sueños y la cuenta de los años» (Sahagún 1979: vol. 1, lib. 3, f. 39r). Pero el franciscano no indica a que edad exactamente comenzaba esta enseñanza y sólo describe la ceremonia de dedicación al calmecac que podía realizarse en los primeros años de vida de un niño noble que, sin embargo, se quedaba en casa de sus padres si era menor de edad. Según el Códice Mendocino, la edad mínima para empezar la educación en el calmecac era 15 años (Codex Mendoza 1992: vol. 1, lám. 65). Si, como suponemos, don Pedro nació en torno a 1512, debía ser demasiado pequeño para ingresar en el calmecac antes de la Conquista. Tal vez tuvo su curso de «educación superior mexica» de forma escondida en los primeros años tras la Conquista, cuando la antigua religión y todas las instituciones relacionadas seguían funcionando clandestinamente. A pesar de que en su testamento don Pedro se declara católico creyente, hay sospechas de que sus vínculos con las creencias y ritos ancestrales eran demasiado estrechos para un hijo ejemplar de la iglesia de Roma, por lo menos en la década de 1530, como veremos adelante. También «el antiguo precioso legado», la tradición histórica oral de los mexicas, era inseparable de las creencias y ceremonias tradicionales.

En el momento de la llegada de los españoles a Tenochtitlan, lo más probable es que Tlacahuepantli estuviera allí con su madre y hermanastros y compartiera cautiverio con Motecuhzoma Xocoyotzin hasta la misteriosa muerte del huey tlahtoani entre el 27 y el 30 de junio de 1520. Posiblemente su minoría de edad en el momento de la Conquista fue uno de los factores que le salvaron la vida en aquel período turbulento. 
El único testimonio de cómo Tlacahuepantli logró salvarse se encuentra también en la Probanza de don Martin de Moctezuma Motlatocazoma. El anciano Pedro García dice que:

«sabe e se acuerda que estando el capitán don Fernando Cortes en la dicha conquista de esta Nueva España y guerras contra este imperio mexicano viendo los indios naturales que el dicho don Pedro de Montezuma era hijo varón de el dicho Montezuma porque no lo matasen los españoles lo tomaron y escondieron y tuvieron oculto muchos días respetandole y acatandole por tal su hijo e señor hasta tanto que el dicho don Fernando Cortés acabó la dicha conquista a él cual se vino el dicho don Pedro e lo trujeron los dichos indios mexicanos siendo muchacho el cual asimismo fue público e notorio que dio la obediencia a Su Majestad y se hizo su vasallo por la forma e orden que el dicho su padre Montezuma El Viejo había dado y esto es la verdad e lo que sabe» (AGN, Tierras, vol. 2627, exp. 1, f. 933r.).

Sin embargo, el viejo testigo prefirió callar un momento importante y no del todo agradable para la nobleza mexica colonial. Tlacahuepantli corría el riesgo de encontrar la muerte no sólo a manos de los conquistadores, sino de sus propios parientes y de los súbditos de su padre. La Crónica Mexicayotl menciona los asesinatos de Xoxopehualoc y Chimalpopoca durante la Noche Triste entre 30 de junio y 1 de julio de 1520, aunque no dice quién fue el culpable (Alvarado Tezozomoc 1975: 150). Axayacatl, el supuesto heredero de Motecuhzoma, habido con su esposa principal, Tecalco, fue también asesinado por los mexicas, algunos días o cuatro meses después de la huida de los españoles de Tenochtitlan, según diferentes versiones (Pérez Rocha 1998: 67; Relación de la genealogía... 1891: 276). Miguel Chimalixtepetla, uno de los testigos de la Información de doña Isabel de Moctezuma, añade que, según la decisión de los nobles tenochcas, debían compartir la misma suerte todos los demás hijos varones de Motecuhzoma (Pérez Rocha 1998: 67). Juan Cano, el último de los seis esposos de doña Isabel de Moctezuma, atribuye el asesinato de Axayacatl al tlahtoani Cuauhtemoc, el desafortunado sucesor de Cuitlahuac (Fernández de Oviedo 1848: 420). La exterminación deliberada de los hijos varones de Motecuhzoma tuvo su efecto, ya que los primeros franciscanos llegados en 1523 encontraron vivos sólo tres hijos varones de Motecuhzoma (Relación de la genealogía ... 1891: 280). Estos tres supervivientes eran el enfermizo Acamapichtli, bautizado después de la Conquista como don Rodrigo de la Paz, que en 1525 fue enviado a España y probablemente murió alli a consecuencia de su enfermedad ${ }^{3}$, don Martín Nezahualtecolotl, habido con una hija del tlahtoani tetzcocano Nezahualpilli, y Tlacahuepantli, bautizado después como don Pedro de Moctezuma.

3 Véase Colección de documentos inéditos... 1885-1932, vol.18, t. V, pág. 33: «Cortés con el presente embio un hijo de Motezuma, llamado Rodrigo, el cual fue puesto en el monasterio de Santo Domingo de Talavera, para que fuese dotrinado en las cosas de la fe». 


\section{Entre los nahuas y los españoles, 1521-1540}

Tras la caída de Tenochtitlan en agosto de 1521, Cortés, que era buen político, decidió asumir el papel de protector de los hijos del difunto huey tlahtoani, especialmente de los menores de edad, lo que le permitía tenerlos en su casa como rehenes valiosos, educarlos en la obediencia al dominio de los españoles e implantar en ellos los principios de la nueva religión y el nuevo modo de vivir. En las primeras décadas tras la Conquista, los religiosos y oficiales españoles, incluso Cortés mismo, intentaron crear un nuevo tipo de élite nahua cristianizada, aculturada y dócil que pudiera servir de intermediaria para negociar con las masas indígenas. Los hijos pequeños y adolescentes de los gobernantes y nobles prehispánicos eran los candidatos ideales para este papel, ya que reunían todas las cualidades deseables. Por un lado, eran generalmente considerados sucesores legítimos de sus padres por los mismos indígenas y, por otro, por su tierna edad, eran más susceptibles a la influencia ajena y carecían del espíritu de rebeldia que caracterizaba a muchos líderes de la generación anterior. Así se abrieron para ellos escuelas como la de Pedro de Gante y el famoso colegio de Santa Cruz de Tlatelolco. Las autoridades españolas confirmaron sus privilegios y les asignaron rentas. En esta categoría estaba don Pedro de Moctezuma. Según la Probanza de don Martin de Moctezuma Motlatocazoma, durante su primera entrevista con Cortés, don Pedro recibió las rentas de unas tierras en el barrio de Atzacualco, en el noreste de Tenochtitlan, que en el período colonial temprano se llamaba San Sebastian Atzacualco (AGN, Tierras, vol. 2627, exp. 1, f. 933v). Posiblemente don Pedro se refiere a estas tierras en su testamento cuando dice: «que él tiene posee en la comarca de México... algunos pedazos de tierras» (Colección Muñoz 1866 vol. 48: 265). Sin embargo Cortés no hizo ninguna gestión para confirmar los derechos de don Pedro a las estancias de Tollan Xicocotitlan, ni a las tierras de Motecuhzoma Xocoyotzin en el valle de Toluca y en el actual estado de Guerrero. Tampoco hizo a don Pedro tlahtoani de Tollan Xicocotitlan. Tras la muerte del tlahtoani Xochitzetzeltzin, en 1521, le sucedió su hermano Ixcuecuechtzin bautizado como don Francisco, que se aprovechó de la Conquista para tomar las tierras de Tlatilco, Milpan, Coayaualco, Teçoquipan, Tlaltzonco, Tepeitec y Xicoco que antes tenían su tío paterno Motecuhzoma Xocoyotzin (Pérez Rocha y Tena 2000: 145). En ese mismo año, el altepetl de Tollan Xicocotitlan con todos sus sujetos fue encomendado al conquistador Gonzalo de Sandoval, el amigo y favorito de Cortés (Ramírez Calva 2005: 74). Don Francisco Ixcuecuechtzin siguió fungiendo como tlahtoani de Tollan o cacique-gobernador, según la nueva terminología novohispana, hasta su muerte en 1527 (Ramírez Calva 2005: 162).

Parece que don Pedro no recibió ninguna educación formal en ninguna de las escuelas organizadas por los primeros frailes franciscanos, ni le enseñaron sistemáticamente la escritura alfabética. Posiblemente en la segunda mitad de su vida aprendió a firmar su nombre, aunque en el poder que don Pedro dió a su procurador Alvaro Ruiz, el 12 de enero de 1557, se dice todavía, que el principe tenochca no lo firmó, «porque dixo que no sabia y firmó un testigo» (AGN, Vínculos y mayorazgos 256, cuad. 12. exp. 1, f. 57r). Sin embargo pudo firmar la primera variante de su testamento el 8 de septiembre de 1570 (Rojas 2001: 385). Es probable también que, gracias a su cerca- 
nía con los conquistadores, don Pedro adquiriera ciertos conocimientos de español, pero el nahuatl siguió siendo el idioma en el que normalmente pensaba y hablaba.

En abril de 1528, Cortés llevó a don Pedro en su viaje a España, el primero después de 24 años de estancia del conquistador en el Nuevo Mundo (Jiménez Abollado 2008: 52). En este viaje le acompañaban también otros 39 jóvenes nobles nahuas, entre ellos don Martin Cortés de Moctezuma Nezahualtecolotl, hermanastro de don Pedro y su primo don Diego de Alvarado Huanitzin, el futuro gobernador de México-Tenochtitlan (Ramírez Calva 2005: 155). Para Cortés este viaje fue de suma importancia, ya que necesitaba justificarse frente a los numerosos cargos levantados contra él, incluso el del supuesto asesinato del juez pesquisidor Luis Ponce de León, que había ido a tomar juicio de residencia al conquistador en julio de 1526 (Martínez 1993 vol. $2: 28,58-59,62)$. En tales circunstancias fue más que conveniente mostrar al emperador la importancia de la conquista de México, y así los jovenes nobles indígenas debían servir como trofeos vivos de aquella victoria. Además, Cortés nunca olvidaba su misión «civilizadora»: los vástagos de los gobernantes nahuas y futuros gobernantes títeres de comunidades indígenas tenían que conocer «las cosas de España» para seguir en el camino de «la vida cristiana» y «buenas costumbres». También era su deber rendir homenaje a su soberano católico.

En septiembre de 1528, Carlos V concedió una audiencia a Cortés y a los jóvenes notables nahuas. Estos últimos recibieron sólo la promesa de guardar sus titulos y jubones de terciopelo, calzones de seda, gorros, medias y zapatos para vestirse «a la española» (Ramírez Calva 2005: 156). Mientras tanto, su «tutor» extremeño, contrajo segundas nupcias con Juana de Zúñiga, la hija del Conde de Aguilar y se le otorgó el titulo del Marqués del Valle junto con una buena porción de tierras en el centro y suroeste de México. Sin embargo, no logró confirmar su cargo de gobernador y capitán general de Nueva España y lo peor de todo, en su ausencia, la Primera Audiencia encabezada por Nuño Beltrán de Guzmán inició el juicio de residencia contra él (Martínez 1993: 11).

Hacia 1530 Cortés se apresuró a volver a Nueva España llevando consigo todos sus «trofeos vivos» incluído a don Pedro. No se sabe nada más de este primer viaje del hijo de Motecuhzoma a España, ni de las impresiones que el joven tuvo del país y de la corte imperial. Pero para él las cosas no iban tan mal como para su protector oficial. En 1527, en Tollan Xicocotitlan, murió su tío don Francisco Ixcuecuechtzin dejando un hijo menor de edad que falleció tres años más tarde, justamente cuando don Pedro regresaba de su viaje (AGN, Vínculos y mayorazgos 256, exp. 1, f. 319v). Hacía 1530 don Pedro se hizo gobernador del «pueblo de Tollan» y un año después, el presidente de la Segunda Audiencia, Sebastian Ramírez de Fuenleal, le confirmó en su cargo. En cuanto a las normas precortesianas, recibir el cargo del gobernante del altepetl significaba el derecho de usufructo de las tlahtocamili, es decir de las tierras de aquellas estancias que los vecinos de Tollan Xicocotitlan nunca reconocieron como patrimonio particular de la dinastía mexica-tenochca. Por el momento esto resolvia el problema, ya que don Pedro recibía las cosechas y el servicio de todas las estancias en cuestión como su «salario» natural por desempeñar funciones administrativas. 
Existen ciertas discrepancias respecto de quien puso al joven don Pedro en el gobierno de Tollan. La Relación de la genealogía y linaje de los señores que han señoreado esta tierra de Nueva España, escrita en 1532 por unos frailes franciscanos allegados del obispo Juan de Zumárraga, dice que fueron los principales de Tollan Xicocotitlan los que pidieron dar a don Pedro el cargo de gobernador del altepetl «que sus primeros antepasados fundaron, que diz que le pertenece de parte de su madre, que es de allí, hija del Señor ya difunto» (Relación de la genealogía... 1891: 280). Pero más tarde, Juan Damian en su apelación, dirigida a la Real Audiencia de México, afirma que lo impusieron los frailes franciscanos contra la voluntad de los vecinos de Tollan (AGN, Vínculos y mayorazgos 256, exp. 1, f. 319v). Ambas fuentes no pueden considerarse testimonios objetivos del acontecimiento. Se sabe que el primer convento franciscano en Tollan Xicocotitlan se fundó en la década de 1520 (Hollingsworth 1991: 30). Desde entonces el convento se convirtió en el centro religioso de toda la «provincia de Tula» y los franciscanos llegaron también a tener gran influencia en los asuntos internos de los pueblos situados en el actual estado de Hidalgo e incluso en su administración. Desde luego ellos podian imponer a don Pedro como cacique-gobernador de Tollan-Xicocotitlan contra la voluntad de sus vecinos. $\mathrm{Al}$ mismo tiempo hay que señalar que la carta de Juan Damian fue escrita en diciembre de 1557, exactamente cuando el odio de los principales y vecinos comunes de Tollan a don Pedro estaba en su apogeo. Así, la afirmación de Juan Damian puede ser una proyección de ese rencor surgido en el curso de una pugna duradera y atroz por las estancias. Es muy probable que al principio los principales de Tollan Xicocotitlan pidieran realmente hacer a don Pedro gobernador de su altepetl, ya que por entonces no había quedado vivo ningun otro varón de la antigua dinastia prehispánica. Para los franciscanos, don Pedro, el protegido de Cortés, joven (rondaba por entonces 18 años), leal, dócil y que parecía «buen cristiano», debía ser también un candidato ideal. En la misma Relación de la genealogía y linaje de los señores que han señoreado esta tierra de Nueva España, se refiere a él como «buena persona» (Relación de la genealogía... 1891: 280). Sin embargo, con el tiempo sus relaciones tanto con los vecinos de Tollan Xicocotitlan como con sus protectores franciscanos empezaron a deteriorarse, hasta el punto de que en 1539 le quitaron su cargo y lo desterraron de Tollan para siempre «por exesos y delitos que hacía y hizo» (AGN, Vínculos y mayorazgos 256, cuad. 12, exp. 1, f. $319 \mathrm{v}$ ).

¿Cuáles podrían ser concretamente estos «delitos»? Sólo se pueden hacer sugerencias al respecto, aunque existen algunas escasas evidencias que nos permiten hipotetizar. En cuanto a sus relaciones con los vecinos de Tollan Xicocotitlan parece que don Pedro simplemente seguía el camino de sus ancestros tenochcas apoyando a sus partidarios y parientes (Ramírez Calva 2005: 161).

Más intrigante parece su relación con los antiguos sacerdotes indígenas que intentaban hacer frente al dominio español. Exactamente en 1539, decepcionado por la conversión superficial de los indígenas y la persistencia de la práctica semioculta de los ritos prehispánicos, el obispo Juan de Zumárraga, que ya tenía experiencia de inquisidor en su patria, inició una serie de procesos inquisitoriales contra los «indios idólatras». Una de sus victimas más famosas fue don Carlos Ometochtzin Chichime- 
catecuhtli, el hijo menor del tlahtoani tetzcocano Nezahualpilli, criado igual que don Pedro en la casa de Hernando Cortés y educado con esmero por los frailes franciscanos. El 2 de julio de 1539, Don Carlos fue detenido por mandato de Zumárraga, acusado de idolatría, herejía, concubinato e incesto, terminando en la hoguera de la Inquisición el 30 de noviembre del mismo año (González Obregón 1910: 4, 82, 84). Uno de los puntos claves de la acusación era el supuesto discurso contra la dominación española que pronunció durante una junta nocturna de los nobles nahuas en el pueblo de Chiconauhtla, a principios de junio de 1539. Don Pedro también asistió a esa junta y desde luego no podía haber evitado escuchar esta filípica antihispana:

«¿quién son éstos que nos deshacen y perturban e viven sobre nosotros y los tenemos a cuestas y nos sojuzgan? Oíd acá, aquí estoy yo y allí está el señor de México, Yoanizi, y allí está mi sobrino Tezapili, señor de Tacuba, y allí esta Tlacahuepantli, señor de Tula, que todos somos iguales y conformes, y no se ha de igualar nadie con nosotros, que ésta es nuestra tierra y nuestra hacienda y nuestra alhaja y posesión, y el señorío es nuestro y a nosotros pertenece; e si alguno quiere facer o decir alguna cosa, reyámonos dello, joh hermanos que estoy muy enojado e sentido! y algunas veces nos hablamos yo e mis sobrinos los señores; ¿quién viene aquí a mandarnos y aprehendernos y a sojuzgarnos? que no es nuestro pariente ni nuestra sangre, y también se nos iguala: piensa que no hay corazón que lo sienta y lo sepa, pues aquí estamos y no ha de haber quien haga burla de nosotros» (González Obregón 1910: 46-47).

No sabemos qué efecto tuvo este discurso sobre don Pedro, ya que ni antes ni después mostró ninguna señal de oposición abierta contra el dominio español. Sin embargo, aún el escuchar estas palabras llenas de ira contra los invasores era, en cierto modo, compartir el crimen, ya que al contrario de otros participantes en aquella junta, don Pedro no salió del aposento donde estaba con don Carlos y se quedó hasta el final de su discurso. Posiblemente le salvó el mismo don Carlos, quien durante el proceso negó definitivamente haber pronunciado semejantes discursos y dijo además que nunca había comunicado estas «herejías» ni a don Pedro ni a otros nobles nahuas (González Obregón 1910: 59). Sin embargo eso no habría bastado para dejar a don Pedro libre de sospechas.

El 20 de junio de 1539 comenzó el proceso del Santo Oficio contra Miguel Pochtecatlailotlac, vecino de México-Tenochtitlan, por ocultar en su casa las imágenes de dioses del antiguo recinto sagrado de Tenochtitlan. Bajo tortura el reo declaró que:

«las guardias de los demonios [las imágenes de dioses prehispánicos] que pusieron en casa de Miguel Pochtecatlaylotlac, que eran: Cuyuchtli, Cauacachtl, Cuychlachitaua son muertos los dichos Coyotch y Calnasacachtli, y es vivo el dicho Coylachiua, que ahora le han dado por nombre Nexpanecatl, el cual solia vivir con el Señor de Tula pasado [Ixcuecuechtzin] y con don Pedro Tlacauepantzi, y el dicho Cuyhlaciua Nexpanecatl era guarda particular de cierto idolo que llamaban Thtlathlauque» [1a cursiva es mia-A.K.] (González Obregón 1912: 181).

Más tarde, en diciembre de 1539, Miguel Pochtecatlailotlac declaró que Coylacihua Nexpanecatl debía saber donde estaban ocultas las imágenes del recinto sagrado (González Obregón 1912: 181). Así mismo un testigo de este proceso, Culuatlapixqui: «que era profeta y tenía la cuenta de los demonios y cargo de hacer 
cosas que para ellos era menester», dijo que había oído de su compañero Tomolo, que en aquel tiempo las imágenes de dioses estaban guardadas en algún lugar cerca de Tollan Xicocotitlan (González Obregón 1912: 124). Si tres años antes uno de los encomenderos locales decía sobre la región de Tollan Xicocotitlan «que toda aquella provincia no sabe qué cosa es Dios» (González Obregón 1912: 5), el hecho de que su gobernador pudiera estar involucrado en ocultar las imágenes de los dioses mexicas y diera refugio en su casa a los antiguos sacerdotes, le mostraba con una luz muy poco favorable a los ojos de las autoridades novohispanas y tampoco le serviría para mantener su cargo.

Las declaraciones de Miguel Pochtectlailotlac fueran hechas el 24 de noviembre de 1539, apenas seis días antes de que don Carlos Ometochtzin fuera quemado en una de las plazas de México (González Obregón 1910: 84). Asimismo, el 2 de diciembre de 1539, comenzó otro proceso contra don Baltasar, el cacique-gobernador de Culhuacan (González Obregón 1912: 177). Obviamente en ese momento la campaña ofensiva contra la nobleza indígena que no quería dejar sus antiguas creencias y costumbres y seguía practicándolas secretamente, iniciada por Zumárraga, alcanzó su auge. Las preguntas hechas a don Carlos y otros reos indican que don Pedro, igual que su primo don Diego de Alvarado Huanitzin, estaba en el círculo de sospechosos y víctimas potenciales de la misma campaña (González Obregón 1910: 59). En estas circunstancias la hostilidad creciente de los principales de Tollan Xicocotitlan le habría hecho especialmente vulnerable, abriendo camino a denuncias y acusaciones contra el hijo del huey tlahtoani, que podían costarle su cargo. Cabe notar que hablando de «exesos crimenes y delitos» de don Pedro que le llevaron a su destitución y destierro, Juan Damian se refiere a un proceso y sentencia contra el príncipe tenochca (AGN, Vínculos y mayorazgos 256, cuad. 12, exp. 1, f. 319v). Lamentablemente su testimonio es único y en este momento no tenemos ninguna documentación relativa a ese proceso.

En comparación con el destino de don Carlos Ometochtzin, la sentencia contra don Pedro fue relativamente suave. ¿Por qué? Posiblemente sus acusadores no encontraron más pruebas para condenarle a un castigo más duro. Otra explicación posible es el patronato real que tenían los hijos y descendientes de Motecuhzoma Xocoyotzin, al menos desde finales de 1520, como herederos de su padre por «la ley natural». Para las autoridades castellanas del siglo XVI, los herederos potenciales de un monarca, aunque gentil, no podían ser tratados como cualquier otro principal, fuesen cuales fuesen sus «delitos». Como veremos más adelante Carlos V y su hijo Felipe II siempre mostraron a don Pedro su apoyo.

Desde el punto de vista de los principales de Tollan Xicocotitlan, al perder su posición de gobernador, don Pedro también perdía cualquier derecho a las tierras de altepetl, incluyendo todas las estancias que él y su madre consideraban como suyas. Por eso no es sorpendente que el nuevo gobernador de Tollan Xicocotitlan, Francisco Aztatl, y los miembros del cabildo del pueblo intentaron tomarlas para sí. Sin embargo, parece que tales acciones no tuvieron un éxito definitivo inmediatamente después del destierro de don Pedro, sino más tarde, en 1540, durante su estancia en España. Si nó sería dificíl explicar por qué don Pedro no reclamó a gritos la restitución de sus 
estancias de Tollan Xicocotitlan ya en su primera probanza, la que hizo junto con don Gabriel Totoquihuaztli, hijo del último gobernante prehispánico de Tlacopan en la Real Audiencia el 4 de diciembre de 1539. En este documento, don Pedro pide las tierras y pueblos de su padre Motecuhzoma y su abuelo paterno Axayacatl en el valle de Toluca (Xiquipilco, Tzacualpan) y en la provincia de Apazco, en el actual estado de Guerrero (Itzquintlapilco) (Pérez Rocha y Tena 2000: 125-26). En cuanto a Tollan Xicocotitlan y su comarca, don Pedro reclamó sólo el pueblo de Atitalaquia (Atitalaquian) y «un barrio de tierras y maceguales que se dice Çayula» de su abuelo materno Ixtlilcuechahuacatl (Pérez Rocha y Tena 2000: 126). Este último ni siquiera aparece en sus peticiones más tardias. Hay un detalle más; en la cédula de Carlos V de 7 de septiembre de 1540, se dice solamente que don Pedro «se teme y recela que los prinçipales y vecinos del dicho pueblo de Tula se havrán entrado e tomado y ocupado las dichas tierras y heredamientos o parte dellos, como lo havían yntentado estando el en essa Nueva España» (Pérez Rocha y Tena 2000: 139). Asi, nuestro príncipe sospechaba, pero no estaba del todo seguro, de que sus enemigos en Tollan reiniciaran sus tentativas de invadir sus posesiones. La meta del segundo viaje de don Pedro a la península obviamente fue otra: obtener de la Corona nuevas mercedes y la confirmación de sus derechos a los pueblos y tierras en las provincias de Toluca y Apazco. Según Hernando de Alva Ixtlilxochitl, el hijo del huey tlahtoani también quería obtener una bula particular del Papa para casarse con una de sus primas.

Que la probanza de 4 de diciembre de 1539 estaba destinada a Carlos V y el Real Consejo de Indias, se puede deducir del hecho de que don Pedro y don Gabriel pidieron las copias de este documento firmadas por el alcalde ordinario de México Luís Marín y el escribano público Alonso Díaz de Gibraleón en sobres sellados, obviamente para presentarlas en la corte del emperador (Pérez Rocha y Tena 2000: 137). En 1540 ambos nobles nahuas ya estaban en España. Según una cédula real a los oficiales de la Casa de Contratación, estuvieron en la península por lo menos hasta el 23 de noviembre de 1540 (AGI, Indiferente General, 1963 1.7, ff. 219v-220r).

¿Quién podría ser la prima con quien don Pedro tanto deseaba casarse? En cuanto a las uniones conyugales de nuestro príncipe la información es excepcionalmente contradictoria y parece que él seguía las costumbres poligínicas de sus ancestros, teniendo relaciones con varias mujeres indígenas de «noble casta y generación» (AGN, Tierras, vol. 2627, exp. 1, f. 821v). Entre sus amores principales se mencionan su prima segunda doña Inés Tiacapan, hija del tlahtoani de Tenayucan Ipampozontzin, la «princesa de Tollan» doña Catalina (¿o Magdalena?) Quiauhxochitl, cierta doña Mencía, también natural de Tollan Xicocotitlan, doña Maria Papiatec de México y doña Francisca, una mujer noble de Tetzcoco (Jiménez Abollado 2008: 53-54). En una carta de Francisco Morales Millán, el consejero de don Pedro en asuntos jurídicos, de 31 de agosto de 1571, se dice que nuestro príncipe estaba casado por la iglesia con doña Inés Tiacapan y los veló fray Cristóbal de Zamora, el guardián del convento franciscano de Tollan Xicocotitlan (AGN, Tierras, vol. 2627, exp. 1, f. 751r/v). De esa union don Pedro tuvo su primer hijo, don Martín Cortés de Moctezuma Motlatocazoma. Sin embargo, en la escritura de mayorazgo y su última carta al rey Felipe II de 1569, don Pedro afirmaba que todos sus hijos, incluso don Martin, eran naturales y 
no estaba casado con ninguna de las mujeres con quienes mantuvo relaciones a lo largo de su vida, salvo su última esposa doña Francisca, de quien no tuvo descendencia (AGN, Tierras, vol. 2627, exp. 1, f. 821v; AGI, Patronato Real 245, R.4, exp. 1, f. 5r). Ixtlilxochitl insiste en que el grado de parentesco entre don Pedro y su primera esposa había sido la causa de que esta unión no fuera reconocida por la Iglesia Católica. Ixtlilxochtil añade que la medio hermana de don Pedro, doña Isabel de Moctezuma, informó a las autoridades eclesiásticas de la Nueva España sobre este impedimento (Alva Ixtlilxochitl 1977 vol. 2: 178). Pero teniendo en cuenta que los indígenas de México eran recién convertidos, la iglesia novohispana admitía matrimonios entre los primos segundos (Molina 1984: 46). Asi, no era necesario pedir una bula del Papa para legitimar esta relación a ojos de los españoles y, como hemos visto en la genealogía del mismo don Pedro, para los mexicas los matrimonios entre parientes era práctica común, que aseguraba la transmisión del rango y los bienes dentro de cierto linaje o su rama. ¿Por qué, entonces, don Pedro negaría más tarde reconocer a doña Inés como su primera y legítima esposa pero volvería a hacerlo en su testamento?

Una explicación posible es el adulterio de doña Inés, cometido durante su ausencia. Algo de lo sucedido cuenta Ixtlilxochitl. Según su relato, mientras el príncipe tenochca andaba por Castilla sin dar noticias, su esposa, creyéndolo muerto, se casó con un conquistador y la bula de la Santa Sede, que don Pedro consiguió con tanto trabajo, ya no servía para nada (Alva Ixtlilxochitl 1977 vol. 2: 177-178). Según otras evidencias, don Pedro acusó a doña Inés de adulterio no con un español sino con su peor enemigo, el nuevo gobernador de Tollan Xicocotitlan, Francisco Aztatl (Ramírez Calva comunicación personal). Así, rencor y celos podían disolver el primer matrimonio de don Pedro mejor que las leyes eclesiásticas. Pero después, con el establecimiento del mayorazgo, el príncipe tenochca se vió obligado a legitimar por lo menos al mayor de sus seis hijos y eso sólo fue posible reconociendo el matrimonio por la Iglesia con la madre de don Martín.

Sin embargo, la documentacion de archivo antes citada nos hace pensar que la preocupación principal de don Pedro fue ganar el apoyo del emperador para confirmar y proteger sus derechos a las posesiones ancestrales y recibir nuevas mercedes para mantener su propia casa y vivir de acuerdo con su posición de único heredero varón de Motecuhzoma Xocoyotzin, ya que por entonces sus hermanastros habrían muerto 4 . Obviamente con la pérdida del cargo de gobernador sus ingresos disminuyeron mucho, puesto que se hacía más y más difícil sacar tributos de sus estancias en Tollan Xicocotitlan y sus únicos recursos seguros eran las rentas de San Sebastian Atzacualco. En cuanto a los pueblos y tierras en Toluca y Apazco, parece que don Pedro no logró recibir nada, porque estas posesiones no aparecen entre sus bienes ni en su escritura de mayorazgo, ni en su testamento. Lo que nuestro príncipe consiguió en lugar de aquellas extensas posesiones, fue una merced de 1.000 pesos de tepuzque (es decir de oro mezclado con cobre) de la real hacienda, bien modesta en comparación con sus esperanzas, que durante los años siguientes fue su única fuente de ingreso sin tomar en cuenta las rentas de San Sebastian (AGI, Patronato Real 245, R.4,

\footnotetext{
${ }^{4}$ Después de los años 1530 desaparece cualquier mención de otros hijos varones de Motecuhzoma.
} 
exp. 1, f. 4v). Posiblemente don Pedro recibió esta merced gracias a la audiencia de Carlos V junto con la cédula de 7 de septiembre de 1540. En este último documento también encontramos el listado ampliado de las estancias de Tollan que don Pedro y su madre consideraban como sus sus pillalli: Yztla, Xitomatla, Tulpan, Tepetlapan, Tlatilco, Coyaualco, Techichilco, Ahuehuepan Tepeitec, Teçoquipan, Xicoco, Toltenco, Teçontepetonco, Yztaqueçaquala, Milpan, Acocolco, Ylocan, Tlaçonco y Teapan (Pérez Rocha y Tena 2000: 139; veáse también el mapa en Ramírez Calva 2005: 69). De acuerdo con el interrogatorio de 1557, fue exactamente en aquel momento cuando don Pedro recibió de su madre, doña María Miahuaxochitl las malas noticias: el nuevo gobernador, los principales y los vecinos de Tollan Xicocotitlan habían logrado invadir sus estancias y repartirlas entre si. En consecuencia él reaccionó pidiendo al emperador dicha cédula y se apresuró a volver a México (AGN, Vínculos y mayorazgos 256 , cuad. 12, exp. 1, f. 78r). Sin embargo, como hemos visto, nada en la cédula prueba que don Pedro supiera con certeza de la «invasión». El interrogatorio de 1557 simplemente presenta una versión de eventos creada a posteriori para ganar el pleito a fines de 1550. Tampoco se puede explicar cómo doña Maria Miahuaxochitl encontró el modo de informar tan rápido a su hijo sobre lo sucedido, estando él al otro lado del Atlántico, separado por meses de camino. Así, resulta que don Pedro conoció el nuevo intento de invasión, esta vez exitoso, ya tras su vuelta a México a principios de 1541 .

\section{La lucha por las tierras de Tollan, 1541-1557}

En la ciudad de México, don Pedro se estableció definitivamente en San Sebastián Atzacualco, junto a la iglesia de San Sebastián, el patrón cristiano del barrio (Colección Muñoz 1866 vol. 48: f. 242r). Ahí estaba su casa, siempre llena de gente, ya que aparte de sus familiares y servidumbre bastante numerosa, casi cada dia solía recibir a sus parientes próximos y lejanos, dignatarios y nobles indígenas, letrados españoles y personas que tenían cualquier tipo de negocios con el hijo del huey tlahtoani. Posiblemente la influencia que adquirió don Pedro gracias a su reconocimento como heredero principal de Motecuhzoma y jefe del pasado linaje gubernamental mexicatenochca, se refleja en la afirmación de Gómara de que él fue «señor de un barrio» (López de Gómara 1852: 434). Sin embargo, no hemos encontrado ninguna mención de que, después de su exilio de Tollan, el príncipe tenochca ocupara algún cargo en el cabildo indígena de México o en los pueblos vecinos.

Aunque el nombre de don Pedro aparece en la carta del gobernador indígena de Tenochtitlan don Esteban de Guzmán al principe Felipe, futuro rey Felipe II, del 19 de diciembre de 1554, en la que se tratan suntos del gobierno indígena de suma importancia, como el nombramiento de los «protectores de indios» para Tenochtitlan y Tlatelolco, él es el único firmante sin cargo adminstrativo (Pérez Rocha y Tena 2000: 194-195).

Vivir al estilo del heredero principal de Motecuhzoma costaba caro y las únicas fuentes de ingresos de don Pedro eran por entonces la antes mencionada merced del 
emperador y las rentas de San Sebastián. A principios de 1541 la situación con las tierras de Tollan se volvió más que drámatica; todas las estancias ya habían sido repartidas entre Francisco Aztatl y sus parientes, miembros del cabildo local. El nuevo gobernador, usando su poder e infuencia entre los pipiltin, consiguió que los tequitlahtoque (organizadores de trabajos colectivos y recolectores de tríbutos) de doña María Miahuaxochitl y don Pedro no acudieran a sus demandas y ninguno de sus parientes en Tollan y sus estancias quiso ayudarles (AGN, Vínculos y mayorazgos 256, cuad. 12, exp. 1, f. 78r/v). En estas circunstancias la «princesa tolteca» no tuvo otro remedio que irse de Tollan, entre llantos y quejas de impotencia, a la casa de su hijo en México (AGN, Vínculos y mayorazgos 256, cuad. 12, exp. 1, f. 80v).

A principios de septiembre de 1541, don Pedro, con la cédula real en la mano puso una demanda al cabildo de Tollan reclamando 11 de las 19 estancias a la Real Audiencia de México, y el virrey Antonio de Mendoza mandó enviar al altepetl un juez de comisión para investigar su caso (AGN, Vínculos y mayorazgos 256, cuad. 12, exp. 1, ff.3r, 13r). Las autoridades novohispanas reaccionaron con entusiasmo moderado y mandaron a Tollan Xicocotitlan a un cierto Juan de Tlaxcala, que como consta por su nombre y un documento de archivo, era natural de «la república de Tlaxcala», un estado independiente en tiempos prehispánicos muy conocido por su enemistad con Tenochtitlan y por su ayuda a Hernando Cortés. Aunque discípulo del famoso colegio de Santa Cruz de Tlatelolco y obviamente bien calificado para su misión, el tlaxcalteca no tenía demasiado interés en defender la causa del príncipe tenochca, hijo del tlahtoani, que antaño se consideraba como el peor enemigo de su patria. El documento que nos queda de su pesquisa, Verba Sociorum Domini Petri Tlacahuepantzi, escrito en latín, nos muestra, que Juan de Tlaxcala interrogó sólo a once testigos, seis de los cuales representaban a la parte contraria y además, tras recibir declaración detallada del primer testigo, Andrés Tlailotlac, se limitó a preguntar a todos los demás si estaban de acuerdo con su testimonio (Pérez Rocha y Tena 2000: 141-143, 147-149). Todo el procedimiento no duró más que un día, el 7 de septiembre de 1541. Asi, don Pedro tenía ciertas razones para quejarse después a los oidores de la Real Audiencia de que el juez tlaxcalteca no hizo su pesquisa tal como era obligado (AGN, Vínculos y mayorazgos 256 , cuad. 12, exp. 1, f. 13r).

En verdad los resultados de esta primera investigación no fueron del todo favorables para el tenochca, ya que los testigos de la parte contraria declararon que las 15 estancias mencionadas en la cédula real de 1540 habían sido en su tiempo usurpadas por el tlahtoani Itzcoatl, por lo que su descendiente no tenía derecho a ellas (Pérez Rocha y Tena 2000: 145). Además, añadió uno de los testigos, Alonso Chichimecatecuhtli, los vecinos de Tollan se apoderaron de esas tierras para poder pagar sus tributos a los españoles.

El único efecto que tuvo la pesquisa de Juan de Tlaxcala fue el marcado crecimiento del odio a don Pedro y de acciones violentas contra sus partidarios y sus propiedades en Tollan Xicocotitlan. Francisco Aztatl y los miembros del cabildo mandaron poner en el cepo a todos los que habían declarado o pudieran declarar a favor de don Pedro, y decidieron derribar sus casas en el altepetl (AGN, Vínculos y mayorazgos 256, cuad. 12, exp. 1, f. 14r). De nada sirvió la carta del virrey Antonio de Mendoza 
al cabildo de Tollan Xicocotitlan, expedida en 7 de octubre de 1542, en la que se ordenaba liberar a los presos, olvidar cualquier intento de destruir los edificios del príncipe tenochca en Tollan y venir a la cuidad México para participar en el pleito. Francisco Aztatl ni siquiera se dignó aceptar el mensaje virreinal (AGN, Vínculos y mayorazgos 256, cuad. 12, exp. 1, f. 15r).

Lejos de darse por vencido, don Pedro presentó una nueva petición demandando hacer una nueva información con «testigos bastantes» (AGN, Vínculos y mayorazgos 256, cuad. 12, exp. 1, f. 15v). El resultado fue nulo y el 7 de febrero de 1543 apareció un nuevo documento, la arriba citada Relación e claridad de la demanda de real de don Pedro e su madre a los de Tula. En consecuencia, en marzo de 1543, el virrey Antonio de Mendoza volvió a mandar al gobernador y miembros del cabildo de Tula ir a la Real Audiencia de Mexico durante 8 días después de recibir su orden y de nuevo los pipiltin de Tula ignoraron este mensaje con una tranquilidad olímpica (AGN, Vínculos y mayorazgos 256, exp. 1, f. 18v). Don Pedro pidió entonces interrogar a sus testigos secretamente por las «pynturas» que tenía (AGN, Vínculos y mayorazgos 256, exp. 1, f. 19v). Los resultados de esta petición son desconocidos. Luego pidió al virrey pasar su caso a Luis de Castilla, el regidor de Tollan o a otro «juez procurador de confianza» para hacer una nueva pesquisa (AGN, Vínculos y mayorazgos 256 , cuad. 12 , exp. 1, f. 20r). Por lo que sabemos de la documentación de archivo, esta última petición se cumplió sólo el 25 de agosto de 1555. Antes, ni siquiera las cédulas de Carlos V y del principe Felipe en favor de don Pedro, de abril y agosto de 1544, lograron poner en marcha la máquina burocrática de la Nueva España (AGN, Vínculos y mayorazgos 256, cuad. 12, exp. 1, ff.54r, 65r).

En 1553 aparece una nueva cédula del principe Felipe, en la que se vuelve a mandar restituir las estancias a don Pedro (AGN. Vínculos y mayorazgos 256, cuad. 12, exp. 1, f. 54r). Este documento, como otros muchos, a lo mejor fue «obedecido», pero no cumplido. Tenemos después una laguna, hasta julio de 1555, probablemente debida a que el príncipe mexica no tenía dinero para continuar con el litigio y pagar el salario a los letrados. Cabe señalar que, dada su formación en la tradición más bien prehispánica que colonial y su poco conocimiento de la escritura alfabética, don Pedro dependía mucho de sus procuradores y consejeros españoles, al principio Alvaro Ruiz en las décadas de 1540 -1550 y Francisco Morales Millán en los 1560, y sus servicios no eran gratuitos.

Su situación financiera debió mejorar algo sólo en el verano de 1555, ya que sabemos que el 7 de julio de 1555 don Pedro reinició su litigio con el cabildo y vecinos de Tollan y el 30 de julio de 1556 aparece un documento muy interesante, el Poder que la dicha doña Maria ratifica los autos a su hijo don Pedro (más adelante Poder de doña María), que en nuestra opinión refleja cambios importantes de argumentación y estrategia por parte de los demandantes (AGN, Vínculos y mayorazgos 256, cuad. 12, exp. 1, f. 55r-56v).

En este último documento, que doña María otorgó a su hijo en la Real Audiencia de México en presencia de los testigos nahuatlato Baltasar Ahuehuate, Pedro Teztapoca (ambos del barrio de San Sebastián) y su propio nieto, Diego Luis Ilhuitemoctzin, ya no se dice nada de que Motecuhzoma Xocoyotzin o gobernantes tenochcas anteriores 
poseían con «justo titulo» por compras o por herencia tierras y estancias alrededor de Tollan, ni que el huey tlahtoani tenochca dio a su hijo menor 10 de las estancias en cuestión, como se afirmaba en la Relación de 1543. El énfasis se pone en los derechos exclusivos de la misma doña Maria Miahuaxochitl, como la heredera legítima de sus padres Ixtlilcuechahuacatl y Huitzilxochitl, a todas las estancias «como bienes de su antepasados» y se afirma que, gracias a su voluntad, don Pedro, como su único hijo también pudo poseerlas y gozar de sus frutos. Por esta razón la «princesa tolteca» da a su hijo: «su poder cumplido libre e lleno e bastante de libre y general administración tan cumplidamente e cual de raçon se require para que por el mismo y por ella y en su nombre pueda proseguir el dicho pleyto ante todos e quales jueces» (AGN, Vínculos y mayorazgos 256 , cuad. 12 , exp. 1 , f. 55 r).

En nuestra opinión, este cambio en justificar los derechos de posesión ya exclusivamente por la línea materna no es casual. Creemos que se adoptó esta nueva argumentación porque los intentos anteriores de don Pedro, en la década de 1540, de probar que su padre, sus abuelos y bisabuelos paternos Axayacatl, Ahuitzotl e Itzcoatl habían poseído las tierras en Tollan con «justo título» como sus pillalli fracasaron, ya que para los principales de Tollan los gobernantes tenochcas nunca dejaron de ser invasores. Don Pedro habría entonces decidido aprovechar los vínculos genealógicos de su madre con la dinastía local, incluso con los gobernantes más antiguos que reinaban en Tollan Xicocotitlan antes de la alianza con mexica-tenochca. El príncipe tenochca prefería callar que su madre tenía hermanos y siempre la presentaba como hija única de Ixlilcuechahuacatl y Huitzillxochitl. Esta argumentación resultó ser más efectiva que la anterior.

En 12 de enero de 1557, don Pedro nombró al español Alvaro Ruiz como su procurador y el 27 de abril de mismo año hizo su nueva probanza ante el teniente del corregidor de Tollan Xicocotitlan, Diego de Almodovar (AGN, Vínculos y mayorazgos 256, cuad. 12, exp. 1. ff. 57r, 80-315r). El documento se abre con el interrogatorio ya citado antes que comprende 25 preguntas y sigue desarrollando la argumentación formulada en el Poder de doña María. En este documento se trata ya de 21 estancias y todas ellas se describen como las posesiones hereditarias de Ixtlilcuechahuacatl y su esposa principal, que heredó su única hija Miahuaxochitl (alias doña María) y que los principales de Tollan usurparon aprovechando la ausencia de su hijo. Tampoco se mencionan a Motecuhzoma Xocoyotzin y a otros gobernantes tenochcas; el conflicto se presentó como un asunto local, choque entre los poseedores legítimos, descendientes de los «señores naturales» de Tollan Xicocotitlan y las nuevas autoridades indígenas corruptas y codiciosas (AGN, Vínculos y mayorazgos 256, cuad. 12, exp. 1, f. 71r-78v). En cuanto al número de testigos, la Probanza de 1557 supera a todos los documentos anteriores, ya que incluye declaraciones de 60 personas, la mayor parte vecinos de las estancias en cuestión, gran parte de los cuales eran tequitlahto$q u e$, es decir recaudadores de tributos y coordinadores de trabajos colectivos para el beneficio de los dueños de los campos. Sus respuestas son unánimes: Ixtlilcuechahuacatl y su esposa poseían las 21 estancias como propiedades hereditarias y, tras su muerte, su hija Miahuaxohitl las recibió sin contradicción alguna, gozando de sus frutos durante su matrimonio con Motecuhzoma Xocoyotzin y luego, por su propia 
voluntad, compartió estos dominios con su hijo don Pedro Tlacahuepantli. Sólo por el temor a las represalias de Francisco Aztatl, los tequitlahtoque y macehualtin dejaron de acudir a sus antiguos señores como debían. No es sorprendente que frente a estos testimonios unánimes, el 25 de octubre de 1557, Diego de Almodovar, teniente del corregidor de Tollan, fallara a favor de la «princesa tolteca» y su hijo (AGN, Vínculos y mayorazgos 256, cuad. 12, exp. 1, f. 315r). Los nuevos poseedores de las estancias, incluso el nuevo gobernador Miguel de Luna Teuctlamacazqui, debían restituirlas inmediatamente a don Pedro y doña María junto con todas las rentas que habían cobrado durante unos 16 años de posesión ilegal.

\section{6. ¿Victorias pírricas? $1557-1570$}

Si el príncipe tenochca creía que su causa había sido ganada y que desde aquel momento podría gozar tranquilamente de los frutos de su lucha, la realidad pronto le mostró lo contrario. Las tierras de las 21 estancias estaban en la zona más fértil para el cultivo, la única donde era posible la agricultura de riego y su pérdida hubiera causado un empobrecimiento tremendo de los macehualtin, que ya vivían en condiciones bien precarias, disminución suficiente de ingresos para la caja de comunidad de Tollan Xicocotitlan y, en consecuencia, graves problemas para el pago de los tributos para el fisco real. En cuanto a los vecinos ordinarios de Tollan Xicocotitlan su primera reacción fue un motín con el intento de matar a don Pedro y solo la horca puesta en la plaza mayor de altepetl moderó su ira (Ramírez Calva 2005: 171). El procurador del cabildo de Tollan, Juan Damian, mandó a la Real Audiencia de México la apelación ya mencionada en nuestro trabajo, afirmando que: 1) las tierras en cuestión nunca fueron propiedades heredetarias, sino que estaban destinadas a mantener a los gobernadores del altepetl; 2) si don Pedro gozaba durante algún tiempo de sus frutos, eso fue solo por ser gobernador de Tollan, cargo que él perdió a causa de sus delitos y abusos; 3) doña María Miahuaxochitl no era la hija del tlahtoani Ixtlilcuechahuacatl, por lo menos legítima; de otro modo ella hubiera heredado el trono de Tollan; 4) todos los testigos que declararon a favor de don Pedro eran personas de poca confianza y además, sobornados por el demandante (AGN, Vínculos y mayorazgos 256, cuad. 12, exp. 1, f. 319r-320r).

Sin embargo, el argumento más decisivo fue el del fiscal Vasco de Puga: «la provincia de Tula» no podría pagar los tríbutos en la cantidad debida sin las tierras de las 21 estancias. Frente a tal argumento el príncipe tenochca no podía hacer nada, por lo que su nuevo pleito con el fiscal fracasó defenitivamente. Don Pedro tuvo que contentarse con 6 de las 21 estancias (Ylocan, Teapan, Techechilco, Ahuehuepan, Teçoquipan, Huapalcalco, Tepeitepec), que en su testamento repartió entre sus seis hijos: don Martín Cortés Motlatocazoma, don Diego Luis Ilhuitemoctzin, don Bartolomé de San Sebastián, doña María, don Lorenzo y doña Magdalena (Colección Muñoz 1866 vol. 48: 265-266). Luego el litigio pasó al Real Consejo de Indias y acabó sólo en 1572, con el reconocimiento de los derechos de don Martin de Moctezuma, el hijo mayor de nuestro principe, para 16 estancias (Jiménez Abollado 2008: 62). 
Por si eso fuera poco, don Pedro no pudo gozar tranquilamente ni de las 6 estancias que le dejaron. En 1561-1562, los principales de Tollan, Pedro de Santiago, Juan Quahuy, Bartolomé Gómez y Pedro Xexel, pusieron nuevas demandas contra don Pedro y su madre; Pedro de Santiago, por la estancia de Ahuehuepan; Juan Quahuy, por la de Teçoquipan; Bartolomé Gómez y Pedro Xexel por las de Huapalcalco y Ylocan, respectivamente (AGN, Vínculos y Mayorazgos 255, cuad. 8, exp.1 f. 1r-72v; AGN, Vínculos y mayorazgos 255, cuad. 8, exp.2, f. 1r-99v.; AGN, Vínculos y mayorazgos 258, cuad. 1, exp.1, f.1r-22r). A pesar de que don Pedro logró ganar estos pleitos, los gastos relacionados con 20 años de litigios junto con su modo de vivir como «gran señor», las obligaciones de pagar los tributos por sus pueblos y mantener a sus familiares, servidumbre y parientes, le arruinaron. Hacía 1566-1567, la suma total de las deudas de don Pedro llegó a la impresionante cifra de 12.000 pesos de oro de minas y el príncipe tenochca podía acabar sus días encarcelado por sus acreedores (AGI, Patronato Real 245, R.4, 1/1, f. 4r). Por aquel momento sus victorias tan costosas en la corte peninsular y juzgados novohispanos parecían pírricas, pero don Pedro, que juzgando por su conducta anterior había heredado algo del espíritu combativo de sus ancestros no iba a rendirse...

El 25 de marzo de 1566, el príncipe tenochca mandó al rey Felipe II una nueva carta pidiendo más mercedes, recordándole los servicios de su padre y poniendo en manifiesto su condición del «hijo único de Motecuhzoma» (Pérez Rocha y Tena 2000: 369). Esta vez la reacción de la Corona fue bastante rápida. Un año más tarde, el 23 de marzo de 1567, Felipe II donó a don Pedro una nueva merced de 3.000 pesos de oro de minas «situados en uno de reparimientos de yndios que en essa tierra estovieren baccos de los pueblos que bacaren», en aquel caso de los indios de Cuauhtitlan, un altepetl lacustre en el noroeste de la Cuenca de México (Pérez Rocha y Tena 2000: 371). Todo por vía de mayorazgo, una institución castellana, que suponía posesión vínculada por línea masculina particular sin posibilidad de enajenar las propiedades en cuestión. El 26 de marzo de 1569, don Pedro firmó la constitución de su mayorazgo para que «descendientes y sucesores tengan mi casa y hacienda y mi nombre, y crezcan y acrecienten el estado de ella» (AGN, Tierras, vol. 2627, exp. 1, f. 812r). Sin embargo, parece que el príncipe tenochca no comprendía del todo la naturaleza de esta institución nueva para él. En vez de la orden de transmisión de herencia de padre a su hijo mayor habido en matrimonio por la Iglesia que supone el mayorazgo, don Pedro, en su última carta al rey Felipe II, pide repartir la renta perpetua de 3.000 pesos entre todos sus hijos «para que lo coman e gasten e destribuyan igualmente», un modelo que más corresponde a la antigua práctica de la élite mexica, cuando los frutos de tierras patrimoniales se distribuían entre todos los miembros de tlahtocamecayotl, o sea, del linaje gubernamental (AGI, Patronato Real 245, R.4, 1/1, f. 5r). ¿Acaso Francisco Morales Millán o fray Domingo de la Anunciación convencieron a don Pedro de que en el caso del mayorazgo tal repartimiento era imposible? Por lo menos, en su testamento don Pedro deja el mayorazgo a su primer hijo don Martín Cortés Moctezuma Motlatocazoma (Colección Muñoz 1866 vol. 48: 266).

La última carta de don Pedro, escrita al rey cinco días después de la escritura de mayorazgo, se puede considerar tambien en cierto modo como un testamento polí- 
Figura 2: Escudo de armas de don Pedro de Moctezuma Tlacahuepantli (AGI, Real Patronato 284, N. 3, f. 64v.).

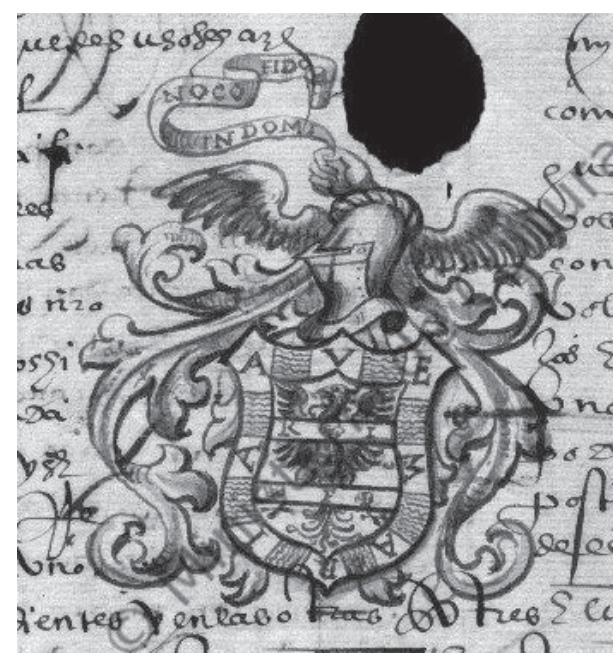

tico del príncipe tenochca para sus descendientes y nos proporciona pistas sobre su autopercepción en los últimos años de su vida. Don Pedro comienza con la descripción de servicios de su padre Motecuhzoma Xocoyotzin, que en su versión sacrificó todo, hasta su propia vida, para el establecimiento de la verdadera fe y grandeza de la Corona castellana (AGI, Patronato Real 245, R.4, 1/1, f. 4r). Él señala que, gracias a la conquista de México o más bien rendición «voluntaria» de Motecuhzoma y sus parientes, España no solo recibió grandes posesiones sino tambien el acceso a las riquezas de otros territorios en América y las islas del océano Pacífico (AGI, Patronato Real 245, R.4, 1/1, f. 4r). Don Pedro sigue alabando la lealtad y diligencia de los nobles indígenas y aun de los macehualtin en servir a la Corona, la Iglesia Católica y sus representantes, que contrasta con las conspiraciones e intentos de rebelión por parte de los antiguos conquistadores y sus descendientes. Luego pasa a la descripción patética de la miseria de la nobleza mexica y de su propia pobreza, que la merced real pudo aliviar sólo parcialmente. Según don Pedro, tal situación era absolutamente injusta, no sólo por los servicios invaluables de su padre y los suyos, sino porque él era el único heredero legítimo de Motecuhzoma, a quien por derecho natural pertenecían todas las riquezas adquiridas por la Corona española. Esta atrevida afirmación, a pesar de todas las apropiadas expresiones de lealtad, se desarrolla en una oferta aún más audaz. El príncipe tenochca promete al rey renunciar en su favor todos los derechos «a estos rreynos de Nueva España» a cambio de aumentar en dos o tres veces la renta perpetua para él y sus descendientes, para que «agora ni en ningun tiempo por via de conciençia ni en otra manera Vuestra Magestad no pueda tener ni tenga ningun escrupulo ni cargo de rrestituçión al linaje de Monteçuma» y promete dar un documento que confirma este acto (AGI, Patronato Real 245, R.4, 1/1, f. 5r). No es posible saber ahora si la idea de negociar con Felipe II en estos términos surgió en la mente de don Pedro gracias a los consejos de su confesor, fray Domingo de Anunciación, o de su consejero Francisco Morales Millán, o fue producto de su propia 
y observaciones de las prácticas castellanas. Lo interesante es que este tipo de negociaciones con la Corona española las adoptaron todos sus descendientes, empezando con su segundo hijo Diego Luis Ilhuitemoctzin, y este mecanismo resultó muy efectivo para incorporarse a la nobleza peninsular, obteniendo poco a poco titulos, mercedes y grandezas (Jiménez Abollado 2008: 63-64, 67-68; López de Meneses 1962: 341-344). Así, en su última carta, don Pedro estableció las bases para que sus descendientes pudieran no solo sobrevivir en un nuevo mundo tan distinto de su ambiente ancestral, sino ocupar en él una posición privilegiada, mostrando verdadero arte para acomodarse a diferentes realidades. Lamentablemente no le quedaba mucho tiempo para aprovecharse de sus resultados.

El hijo del huey tlahtoani falleció en su propia casa en la ciudad de México el 11 de septiembre de 1570, tras otorgar tres días antes su testamento en presencia de su confesor fray Domingo de Anunciación, su consejero y representante jurídico Francisco Morales Millán, su esposa doña Francisca y sus hijos Martin, Bartolomé, Lorenzo, María y Magdalena (Diego Luis por entonces estaba en Castilla tratando pleitos de su padre en la corte real), y los testigos: escribano público Damian García, nahuatlato Francisco de Osorio, Diego de Escobedo y Pedro Valdes (Colección Muñoz 1866 vol. 48: 285). En el testamento, entre otros mandamientos, se menciona la fundación de la capellanía «para que del dicho linaje de Motezuma quede memoria» y donación al colegio de San Juan de Letrán, destinado para educación de los niños indígenas (Colección Muñoz 1866 vol. 46: 280).

Es una amarga ironía el que don Pedro fuese definitivamente reconocido por la monarquía de los Habsburgos como único legítimo heredero de Motecuhzoma Xocoyotzin solo en... el día de su muerte. El 11 de septiembre de 1570, cuando el príncipe tenochca exhaló su último suspiro, al otro lado del Atlántico, en Madrid, Felipe II le concedió el mismo escudo de armas que años antes, en 16 de febrero de 1536, habia sido concedido a su medio hermano mayor don Martín Cortés de Moctezuma Nezahualtecolotl, que hasta su temprana muerte y lo, más probablemente, sin descendencia, obviamente se consideraba como el heredero varón principal del huey tlahtoani (Villar Villamil 1933: 125; AGI, Patronato Real 284, N.3, f. 64v). La cédula respectiva del rey indicaba que esta merced se otorgaba a don Pedro y sus hijos en señal de recompensa por méritos y servicios de su padre, «que ayudó y favoreció» a Hernando Cortés en la conquista de sus propios dominios y las muestras de lealtad del mismo don Pedro (AGI, Patronato Real 284, N.3, f. 64r). Lo mismo constaban las imágenes simbólicas del escudo: el águila negra de los Habsburgos, las rosas doradas de la Virgen e iniciales de Carlos V, su esposa Isabel de Portugal y su hijo Felipe II reemplazaron para siempre el águila marrón, nopal y serpiente de los mexicas (véase Figura 2). Desde aquel momento, el destino de los descendientes de don Pedro ya era inseparable del mundo de los conquistadores que destruyeron tan brutalmente el universo de su padre. 


\section{Referencias documentales}

AGI (Archivo General de Indias)

Indiferente General, 1963 1.7, f. 219v-220r: «Real Cédula a los oficiales de la Casa de Contratación», 1540.

Patronato Real 245, R.4, exp. 1, f. 4v-5v: «Carta de don Pedro de Moctezuma al rey Felipe II», 1569.

Real Patronato 284, N.3, f. 64r/: «Concesión de armas para don Pedro de Moctezuma», 1570.

AGN (Archivo General de la Nación, México)

Tierras, vol. 2627, exp. 1, f. 819r-821v: «Mayorazgo de don Pedro de Moctezuma», 1570.

Tierras, vol. 2627, exp. 1, f. 917r-933v: «Probanza de don Martín Moctezuma», 1572.

Vínculos y mayorazgos 255, cuad. 8, exp. 1, f. 1r-72v: «Pedro de Santiago del pueblo de Tula contra Pedo de Moctezuma y doña María su madre sobre tierras», 1561-1562.

Vínculos y Mayorazgos 255, cuad. 8, exp. 2, f. 1r-20v: «Probanza de Juan Quahuy por las tierras de Tezoquipan», 1561.

Vínculos y mayorazgos 256, cuad. 1, exp. 1: Relación de la claridad y demanda de don Pedro y su madre

Vínculos y mayorazgos 256, cuad. 12, exp. 1, f. 13r: «Petición de don Pedro de Moctezuma al presidente y los oidores de la Real Audiencia de México», 1541.

Vínculos y mayorazgos 256, cuad. 12, exp. 1, f. 14r-15r: «Carta de don Pedro de Moctezuma al virrey Antonio de Mendoza en razón de las casas y otras cosas », 1542.

Vínculos y mayorazgos 256, cuad. 12, exp.1, f.15v: «Carta-petición de don Pedro de Moctezuma al virrey Antonio de Mendoza y los oidores de la Real Audiencia», 1542.

Vínculos y mayorazgos 256, cuad. 1, exp.1, f.18r-19v: «Relación de la demanda de real de don Pedro e su madre a los de Tula e cómo se ceden en las tierras de que piden posesión», 1543.

Vínculos y mayorazgos 256, cuad. 1, exp.1, f. 20r: «Enplazamiento de don Pedro de Moctezuma contra los indios principales de Tula», 1543.

Vínculos y mayorazgos 256, cuad. 12, exp.1, f.54r: «Real cédula del empedador Carlos V a favor de don Pedro de Moctezuma», 1544.

Vínculos y mayorazgos 256, cuad. 12, exp.1, f. 55r-56v: «Poder que la dicha doña Maria ratifica los autos a su hijo don Pedro», 1556.

Vínculos y mayorazgos 256, cuad. 12, exp.1, f. 57r: «Nombramiento del procurador de don Pedro de Moctezuma», 1557.

Vínculos y mayorazgos 256, cuad. 12, exp.1, f.71r.-78r: «Interrogatorio presentado por don Pedro de Moctezuma y doña María Miahuaxochitl», 1557.

Vínculos y mayorazgos 256, cuad. 12, exp.1, f.80r-249v: «Probanza de don Pedro de Moctezuma», 1557.

Vínculos y mayorazgos 256, cuad. 12, exp.1, f.293r-294v: "Ynterogatorio de tachas presentado por el gobernador y el cabildo de Tula», 1557.

Vínculos y mayorazgos 256, cuad. 12, exp.1, f. 315r/v: «Sentencia a favor de don Pedro de Moctezuma y de su madre», 1557.

Vínculos y mayorazgos 256, cuad. 12, exp.1, f. 319r-320r: «Carta de Juan Damián indio principal del pueblo de Tula», 1557.

Vínculos y mayorazgos 258, cuad. 1, exp.1, f.1r-22r: «Probanza de Bartolomé Goméz y Pedro Xexel», 1561. 


\section{Referencias bibliográficas}

Acosta, Jorge

1940 «Exploraciones en Tula Hgo». Revista Mexicana de Estudios Antropológicos 4: 172-194.

1956-57 «Interpetaciones de algunos datos obtenidos en Tula relativos a la época tolteca». Revista Mexicana de Estudios Antropológicos 14: 75-110.

Alva IxtLilXochith, Hernando

1975-77 Obras históricas, 2 vols. México: UNAM.

Alvarado Tezozomoc, Hernando

1975 Cronica Mexicayotl. México: UNAM

2001 Cronica Mexicana. Madrid: Dastin Historia.

Anales de Tula

1979 Anales de Tula, con comentario de Rudolf van Zantwijk. Graz: Akademische Druck und Verlagsanstalt.

Chimalpahin, Domingo Francisco

2003 Las ocho relaciones y el memorial de Culhuacan. México: CONACULTA.

Chipman, Donald

2005 Moctezuma's Children: Aztec Royalty under Spanish Rule, 1520-1700. Austin: University of Texas Press.

Códice Mendoza

1992 Codex Mendoza, edición de Frances Berdan and Patricia Rief Anawalt. Berkeley: University of California Press.

Colección de documentos inéditos...

1885-32 Colección de documentos inéditos relativos al descubrimiento, conquista y organización de las antiguas posesiones españoles de ultramar, 42 vols. Madrid: Rivadeneyra.

\section{COLECCIÓN MuÑoz}

1866 «Testamento y fundación de mayorazgo otorgado por D. Pedro Motezuma en 8 de setiembre de 1570, y varios otros documentos relativos a la sucesion en el mismo», en Colección de Juan Bautista Muñoz, vol. 48, pp. 239-263. Madrid: Real Academia de la Historia.

Fernández de Oviedo y Valdés, Gonzalo

1848 «Diálogo del Alcaide de la Fortaleza de la Ciudad de Santo Domingo de la Isla Espanola Autor y Chronista de Estas Historias, de Una Parte e de la Otra, un Caballero Vecino de la Gran Cuidad de Mexico llamado Ihoanm Cano», en Antiquities of México, E. K. Kingsborough, ed., vol. 8, pp. 419-425. Londres: Whittetaker and Co.

GonZÁlez OBREGón, Luis (ed.)

1910 Proceso criminal del Santo Oficio de la Inquisicion y del fiscal en su nombre contra don Carlos, Indio Principal de Tezcoco. México: Publicaciones del Archivo General de la Nación.

1912 Procesos de indios idolatras y hechiceros. México: Publicaciones del Archivo General de la Nación. 
Hollingsworth, Ann Prather

1992 Pedro de Moctezuma and his descendents. Ann Arbor: University of Michigan Press.

JimÉNEZ ABollado, Francisco

2008 «Don Diego Luis Moctezuma, nieto de Hueytlatoani, padre de conde: un noble indígena entre dos mundos». Anuario de Estudios Americanos 65: 49-68.

LÓPEZ DE GÓMARA, Francisco

1852 Hispania Victrix. Segunda parte de la Historia General de las Indias. Madrid: Imprenta y estereotipia de M. Rivadeneyra.

LÓPEZ LuJÁN, Leonardo y Alfredo LÓPEz Austin

2009 «The Mexica in Tula and Tula in Mexico-Tenochtitlan», en The Art of Urbanism: How Mesoamerican Kingdoms Represented Themselves in Architecture and Imagery, William L.Fash and Leonardo López Luján, eds, pp. 384-422. Washington: Dumbarton Oaks Research Library and Collection.

López de Meneses, Amada

1948 «Tecuichpoctzin Hija de Moteczuma (1510?-1550)». Revista de Indias 9: 31-47.

1962 «Grandezas y títulos de nobleza a los descendientes de Moteczuma». Revista de Indias 89-90: 341-352.

Martínez, José Luis (ed.)

1994 Documentos Cortesianos: Primera y Segunda Seccion, 3 vols. Mexico: UNAM Fondo de Cultura Económica.

Molina, Alonso de

1984 Confesionario mayor de la lengua mexicana y castellana. México: UNAM.

Nazareo, Pablo

2000 «Carta de don Pablo Nazareo al rey Felipe II en latín, México», en La nobleza indigena del centro de México después de la Conquista, Emma Pérez Rocha y Rafael Tena, eds., pp. 333-367. México: INAH.

Perez Rocha, Emma

1998 Privilegios en lucha: Información de doña Isabel de Moctezuma. Mexico: INAH.

Perez Rocha, Emma y Rafael Tena

2000 La nobleza indigena del centro de México después de la Conquista. Mexico: INAH.

Pimentel, Hernando

2000 «Carta de don Hernando Pimentel Nezahualcoyotl al rey Felipe II: en español, Tetzcoco, 6 abril 1562», en La nobleza indigena del centro de México después de la Conquista, Emma Pérez Rocha y Rafael Tena, pp. 257-258. México: INAH.

Ramirez CALVA, Verenice

2005 Caciques y cacicazgos indígenas en la región de Tollan, siglos XVI-XVII. Tesis Doctoral. Zamora: Colegio de Michoacán.

RELACión de LA GENEALOGÍA

1891 «Relacion de la genealogia y linaje de los señores que han señoreado esta tierra de Nueva España», en Nueva colección de documentos para historia de México, edición de Joaquín García Icazbalceta, vol. 3, pp. 263-281. México: Imprenta Francisco Díaz de León. 
RoJAs, José Luis de

2001 «Por el humo se sabe dónde está el fuego. Evidencias de la complejidad social novohispana en el testamento de don Pedro Moctezuma (siglo XVI)». Revista de Investigaciones Juridicas 25: 379-392.

SAHAGÚn, Bernardino de

1979 Historia general de las cosas de la Nueva España, 3 vols. México: Fondo de Cultura Economica.

Villar Villamil, Ignacio de

1933 Cedulario heráldico de conquistadores de Nueva España. México: MNAHE. 